\title{
Differential targeting of the cyclin-dependent kinase inhibitor, p21 2 CIP1/WAF1, by chelators with anti-proliferative activity in a range of tumor cell-types
}

\author{
Rayan S. Moussa1, Zaklina Kovacevic ${ }^{1}$, Des R. Richardson ${ }^{1}$ \\ ${ }^{1}$ Molecular Pharmacology and Pathology Program, Discipline of Pathology and Bosch Institute, Blackburn Building (D06), The \\ University of Sydney, Sydney, New South Wales, 2006, Australia
}

Correspondence to:

Des R. Richardson, e-mail: d.richardson@med.usyd.edu.au

Zaklina Kovacevic, e-mail: zaklina.kovacevic@sydney.edu.au

Keywords: DFO, Dp44mT, p2 $1^{\text {CIPI/WAFI }}$, p53, MDM2

Received: June 21, $2015 \quad$ Accepted: August 10, 2015

Published: August 22, 2015

\section{ABSTRACT}

Chelators such as 2-hydroxy-1-napthylaldehyde isonicotinoyl hydrazone (311) and di-2-pyridylketone-4,4-dimethyl-3-thiosemicarbazone (Dp44mT) target tumor cell iron pools and inhibit proliferation. These agents also modulate multiple targets, one of which is the cyclin-dependent kinase inhibitor, p21. Hence, this investigation examined the mechanism of action of these compounds in targeting p21. All the chelators up-regulated p21 mRNA in the five tumor cell-types assessed. In contrast, examining their effect on total p21 protein levels, these agents induced either: (1) down-regulation in MCF-7 cells; (2) up-regulation in SK-MEL-28 and CFPAC-1 cells; or (3) had no effect in LNCaP and SK-N-MC cells. The nuclear localization of p21 was also differentially affected by the ligands depending upon the cell-type, with it being decreased in MCF-7 cells, but increased in SK-MEL-28 and CFPAC-1 cells. Further studies assessing the mechanisms responsible for these effects demonstrated that p21 expression was not correlated with p53 status, suggesting a p53-independent mechanism. Considering this, we examined proteins that modulate p21 independently of p53, namely NDRG1, MDM2 and $\triangle$ Np63. These studies demonstrated that a dominant negative MDM2 isoform ( $17^{\mathrm{MDM} 2}$ ) closely resembled p21 expression in response to chelation in three cell lines. These data suggest MDM2 may be involved in the regulation of $\mathrm{p} 21$ by chelators.

\section{INTRODUCTION}

Iron $(\mathrm{Fe})$ deprivation via the use of chelators, has been shown to lead to $\mathrm{G}_{1} / \mathrm{S}$ arrest in neoplastic cells [1-7]. In fact, cellular $\mathrm{Fe}$ levels modulate the expression of molecules involved in cell cycle control, including cyclins, cyclin-dependent kinases (cdk), cdk inhibitors, as well as tumor suppressor and metastasis suppressor genes [8-12]. Since neoplastic cells have a greater need for Fe, they are more susceptible to the effects of Fe chelation when compared to normal cells $[13,14]$. Thus, by inhibiting Fe availability to tumors, cancer cell proliferation can be effectively blocked, indicating that targeting $\mathrm{Fe}$ and other essential metals is a significant new therapeutic strategy $[9,15,16]$.
Desferrioxamine (DFO; Fig. 1) is a well known Fe chelator that is clinically used for the treatment of the Fe overload disease, $\beta$-thalassemia [15]. The potential of chelators as anti-cancer agents was realised when DFO was trialled in a number of in vitro and in vivo studies, some of which showed promising results $[1,4,5,17]$. Although DFO has shown anti-proliferative activity, the high hydrophilicity of this ligand limits its membrane permeability and anti-tumor efficacy $[18,19]$. As a result of this problem and its short half-life in the circulation, DFO must be administered via subcutaneous infusion for extensive periods, making it inconvenient for patients [15].

Due to the limitations of DFO, alternative chelators have been developed in the quest to create more potent and selective anti-cancer agents [15]. For example, 


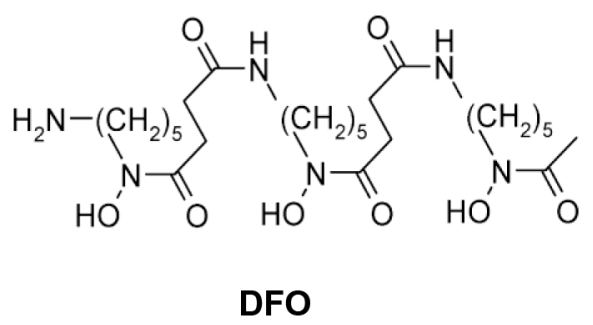

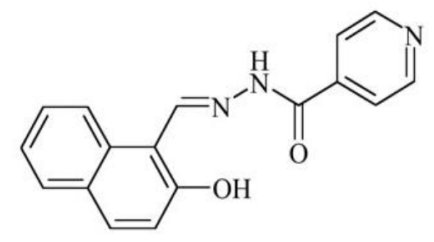

311<smiles>CN(C)C(=S)NN=C(c1ccccn1)c1ccccn1</smiles>

Dp44mT

Figure 1: Line drawings of the structures of the chelators: DFO, 311 and Dp44mT.

2-hydroxy-1-napthylaldehyde isonicotinoyl hydrazone (311; Fig. 1), is a ligand of the pyridoxal isonicotinoyl hydrazone (PIH) class that has been shown to be more effective at chelating cellular Fe than DFO, and this can be explained by its greater lipophilicity [20-22]. Furthermore, di-2-pyridylketone 4,4-dimethyl-3-thiosemicarbazone (Dp44mT; Fig. 1), is a novel agent from the dipyridyl thiosemicarbazones (DpT) class of chelators that has been demonstrated to have markedly greater anti-proliferative activity and Fe chelation efficacy than DFO and is highly effective at reducing growth and metastasis of multiple tumors in vitro and in vivo [23-26]. An important aspect of the activity of the DpT class of thiosemicarbazones (e.g., Dp44mT) is their ability to: (1) up-regulate the potent metastasis suppressor, N-myc downstream regulated gene-1 (NDRG1) [12, 25], which inhibits the epithelial mesenchymal transition [27] through its effect on a number of oncogenic signaling pathways [14, 27-31]; and (2) their ability to overcome multi-drug resistance [24] by causing lysosomal membrane permeabilization via their metal-induced redox activity $[32,33]$. In fact, the DpT series of ligands form redox-active complexes with Fe and copper, which leads to the generation of reactive oxygen species (ROS) that enhance cellular toxicity [33-35].

In order to develop these agents further, and to better understand their mechanisms of action, the effects of chelators on the expression of cell cycle control molecules require further elucidation. In fact, apart from up-regulating NDRG1, chelators were found to affect a number of crucial molecules that are involved in proliferation and apoptosis [36]. Among these, cellular Fe chelation up-regulates the expression and transcriptional activity of the tumor suppressor, p53 [10, 37]. Additionally, Fe depletion increased p53 phosphorylation, which stabilizes the p53 protein, preventing its proteasomal degradation [38]. Notably, p53 plays a key role in regulating the expression of genes involved in cell cycle arrest and apoptosis in response to genotoxic damage or cellular stress [39].

Thus, NDRG1 and p53 are important molecular targets of chelators, which are crucial to the anti-cancer and anti-metastatic activity of these agents $[10,12,16]$. These molecules and their downstream protein targets present ideal therapeutic strategies for the treatment of cancer. In fact, the cdk inhibitor, p21, is a common downstream target for both p53 [40] and NDRG1 [41] and plays an important role in the inhibition of cell cycle progression and proliferation [42, 43], as well as prevention of metastasis [44].

Significantly, p21 plays a variety of physiological roles, many of which rely on its nuclear localization [45]. These include its cdk inhibitory function, promotion of differentiation and of cellular senescence [45]. For instance, p21 inhibits the cyclin D/cdk4/6 and the cyclin $\mathrm{E} / \mathrm{cdk} 2$ complexes in response to DNA-damage, resulting in $\mathrm{G}_{1} / \mathrm{S}$ arrest [46]. In addition, p21 also binds to the DNA replication/repair factor, proliferating cell nuclear antigen (PCNA), interfering with its DNA replication, but not DNA repair activity $[47,48]$. Paradoxically, when localized (at least initially) to the cytosol, p21 can aid cell cycle progression and play vital pro-proliferative and cell survival roles [45]. At low levels, p21 can aid cell cycle progression, by stabilizing interactions between cdk4/6 and cyclin D1 $[49,50]$. Notably, p21 also has anti-apoptotic 
functions when up-regulated in tumor cells [51]. Considering its crucial role [46, 49], it is vital to elucidate how p21 responds to Fe-depletion in various cancer cells and whether it can be utilized as a therapeutic target.

The current study investigated the mechanisms involved in the chelator-mediated regulation of $\mathrm{p} 21$. Five cancer cell lines with different p53 status were incubated with either of three ligands, namely: DFO, 311 or Dp44mT. In addition, the well characterized DNA-damaging agents: actinomycin D (Act D), cisplatin (CP) and mitomycin C (MC) [52-55], were also used throughout this study as positive controls. Hence, for the first time, the effect of a variety of effective chelators could be assessed relative to a range of DNA-damaging agents to assess the mechanism involved. These results revealed a number of significant outcomes, namely: (1) the effect of the chelators on p21 differed between the cell-types examined, with $\mathrm{p} 21$ protein being up-regulated in SK-MEL-28 and CFPAC-1 cells, down-regulated in MCF-7 cells, and left unchanged in LNCaP and SK-N-MC cells; (2) the nuclear localization of p21 was also differentially affected by the ligands depending upon the cell-type, with it being decreased in MCF-7 cells, but increased in SK-MEL-28 and CFPAC-1 cells; (3) the p53 status of the cells examined showed no correlation to the chelator-mediated effects on $\mathrm{p} 21$, suggesting a p53-independent effect; and (4) examination of molecules that can modulate p21 independently of p53, namely NDRG1 [41], mouse double minute 2 homolog (MDM2) [56, 57] and $\Delta \mathrm{Np} 63$ [58-61], revealed that a dominant negative MDM2 isoform ( $75^{\mathrm{MDM} 2}$ ) closely resembled p21 expression in response to chelation in three of the five cell lines examined. In fact, the $\mathrm{p} 75^{\mathrm{MDM} 2}$ isoform has been shown to interfere with the ability of the fulllength MDM2 ( $\mathrm{p} 90^{\mathrm{MDM} 2}$ ) to degrade its target proteins [62], which include p53 and p21 [56, 57, 63, 64]. These data suggest that MDM2 may be one effector through which chelators regulate p21 expression in these cell-types.

\section{RESULTS}

\section{Incubation with chelators or DNA-damaging agents up-regulates p21 mRNA expression}

To examine the effect of chelators on $\mathrm{p} 21$ expression, our initial studies focused on examining p21 mRNA levels in five different cell-types, namely: MCF-7, LNCaP, SK-MEL-28, CFPAC-1 and SK-N-MC cells (Fig. 2A-2E). These cell lines were specifically chosen due to their varying p53 status (Table 1), with MCF-7 and LNCaP cells expressing wild-type (WT) p53, while SK-MEL-28 and CFPAC-1 cells express mutant p53, and SK-N-MC cells are p53 null [65-69]. Considering that p53 is an important transcriptional activator of p21 [39], we initially hypothesised that p21 expression could correlate to p53 status and activity in the cells examined.

In these studies, a $24 \mathrm{~h}$ incubation with the chelators, $311(25 \mu \mathrm{M})$, Dp44mT $(2.5 \mu \mathrm{M})$ and DFO $(250 \mu \mathrm{M})$ was utilized. These concentrations were used due to the relative permeability and efficacy of these ligands. Indeed, DFO is highly hydrophilic and does not permeate cell membranes effectively [19], while 311 and Dp44mT are both lipophilic and easily permeate cell membranes to chelate intracellular Fe pools [21, 23]. A lower concentration of $\mathrm{Dp} 44 \mathrm{mT}$ was used relative to 311 due to the markedly greater anti-proliferative activity of the former compound $[21,23]$. These concentrations also allowed comparisons to the results obtained in previous studies using these agents $[14,70]$. After all incubations at these concentrations, the cell monolayer remained intact and the cells were viable.

Using these experimental conditions with the chelators, a significant $(p<0.001-0.05)$ up-regulation in $p 21 \mathrm{mRNA}$ levels was observed across all cell-types examined when compared to untreated control cells (Fig. 2A-2E). The DNA-damaging agents, Act D (5 nM), $\mathrm{CP}(20 \mu \mathrm{M})$ and $\mathrm{MC}(30 \mu \mathrm{M})$, were used as positive controls, as these conditions are known to markedly upregulate p21 mRNA in MCF-7 cells [12]. Following a $24 \mathrm{~h}$ incubation, both $\mathrm{CP}$ and $\mathrm{MC}$ significantly $(p<0.01-$ 0.05 ) up-regulated $p 21 \mathrm{mRNA}$ levels in each of the celltypes examined (Fig. 2A-2E). In contrast, while Act D increased $p 21 \mathrm{mRNA}$ relative to the control, the effect was variable between cell-types, with no marked up-regulation occurring for SK-MEL-28 (Fig. 2C) and CFPAC-1 (Fig. 2D). On the other hand, a marked and significant $(p<0.01)$ up-regulation of $p 21 \mathrm{mRNA}$ occurred when MCF-7, LNCaP and SK-N-MC cells were treated with Act D relative to the control (Fig. 2A, 2B, 2E).

A well characterised molecular target of $\mathrm{Fe}$ depletion, namely $N D R G 1[12,25]$, was also used as a positive control for Fe-mediated regulation by the chelators. As shown in Fig. 2A-2E, in all five cell-types the chelators resulted in a significant $(p<0.01-0.05)$ increase in NDRG1 mRNA levels relative to the control, which is in agreement with earlier studies [12]. The DNAdamaging agents displayed no significant $(p>0.05)$ effects on $N D R G 1$ expression in these cell lines.

In summary, in each of the cell lines examined, the chelators were able to markedly up-regulate $p 21$ mRNA levels, regardless of the p53 status of the cell (Table 1). These results suggest that the chelators may regulate p21 mRNA independently of p53 status.

\section{p53-independent regulation of $\mathrm{p} 21$ protein in response to $\mathrm{Fe}$ chelators}

Previous studies $[70,71]$ demonstrated that although DFO or 311 increased $p 21$ mRNA expression in MCF-7 

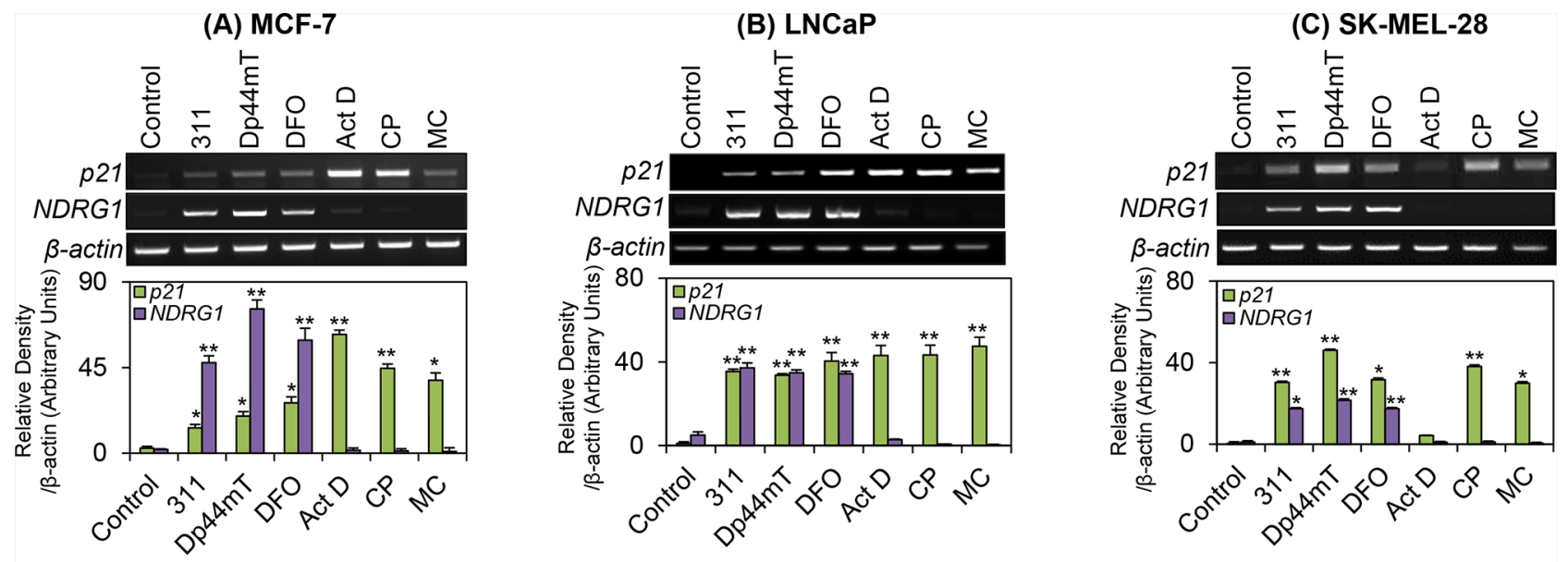

(D) CFPAC-1

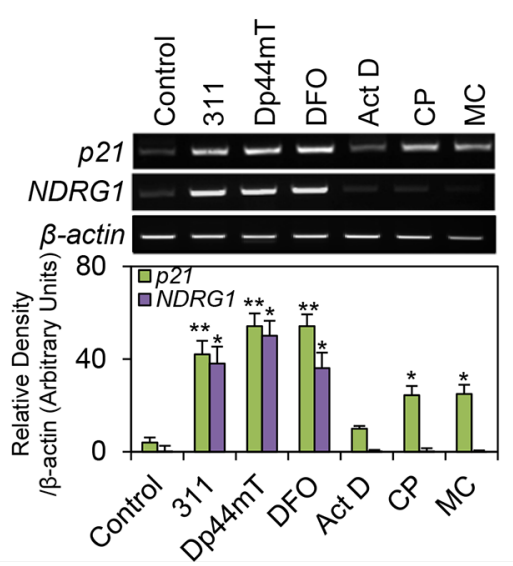

(E) SK-N-MC

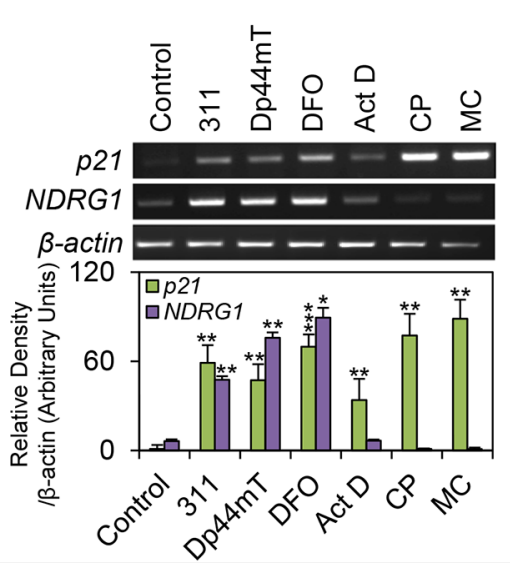

Figure 2: The effect of the chelators 311, Dp44mT, or DFO, and the DNA-damaging agents, Act D, CP or MC on p21 or NDRG1 mRNA levels in five different tumor cell lines. A. MCF-7; B. LNCaP; C. SK-MEL-28; D. CFPAC-1; and E. SK-N$\mathrm{MC}$ cells. Cells were incubated for $24 \mathrm{~h} / 37^{\circ} \mathrm{C}$ with the chelators, $311(25 \mu \mathrm{M})$, Dp44mT $(2.5 \mu \mathrm{M})$, DFO $(250 \mu \mathrm{M})$, or the DNA-damaging agents, Act D $(5 \mathrm{nM}), \mathrm{CP}(20 \mu \mathrm{M})$, or $\mathrm{MC}(30 \mu \mathrm{M})$. The gels are typical of 3 independent experiments, while the densitometric analysis is mean \pm SD (3 experiments). Relative to control: ${ }^{*} p<0.05,{ }^{* *} p<0.01,{ }^{* * *} p<0.001$.

cells, the protein levels of $\mathrm{p} 21$ were markedly reduced by these agents. To further investigate this, the next series of studies focused on examining the protein levels of p21 in all five cell lines. Under control conditions, MCF-7 cells expressed relatively high levels of p21 protein (Fig. 3A). In agreement with previous findings [70,71], the protein levels of p21 were significantly $(p<0.01-0.05)$ decreased by the chelators in this cell line, when compared to the control (Fig. 3A). This effect was in contrast to the up-regulation of $p 21 \mathrm{mRNA}$ levels that was observed after incubation of MCF-7 cells with these agents relative to control medium (Fig. 2A). However, the DNA-damaging agents, Act D and CP, significantly $(p<0.01-0.05)$ increased the levels of p21 protein in MCF-7 cells (Fig. 3A), which was in agreement with their effect on p21 mRNA expression (Fig. 2A). The effect of Act D and $\mathrm{CP}$ on increasing $\mathrm{p} 21$ protein was expected based on the fact that MCF-7 cells express wild-type p53 which responds to DNA damage [39] (Table 1). However, unexpectedly, treatment of MCF-7 cells with the DNAdamaging agent, $\mathrm{MC}$, resulted in a significant $(p<0.01)$ decrease in $\mathrm{p} 21$ protein expression relative to the control (Fig. 3A).

In contrast to MCF-7 cells, incubation of $\mathrm{LNCaP}$ cells with 311 , Dp $44 \mathrm{mT}$, or DFO, failed to significantly $(p>0.05)$ alter $\mathrm{p} 21$ protein levels relative to the control (Fig. 3B). However, incubating LNCaP cells with the DNA-damaging agents, Act $\mathrm{D}, \mathrm{CP}$, or $\mathrm{MC}$, also resulted in a marked and significant $(p<0.001-0.05)$ increase in p21 levels relative to the control (Fig. 3B). Considering that $\mathrm{LNCaP}$ cells also express wild-type p53 (Table 1; [65]), the observed effect of DNAdamaging agents on the up-regulation of $\mathrm{p} 21$ expression was expected. 
In contrast to MCF-7 and LNCaP cells, using SK-MEL-28 and CFPAC-1 cells, chelators markedly $(p<0.001-0.01)$ increased $\mathrm{p} 21$ levels in comparison to the untreated controls (Fig. 3C, 3D). However, relative to the control, there were no significant $(p>0.05)$ alterations in $\mathrm{p} 21$ protein levels following incubation with the DNAdamaging agents in both these cell lines, and this could be due to the fact that they possess mutated p53 [66, 68]. Clearly, this response to chelation and DNA-damaging agents by SK-MEL-28 (Fig. 3C) and CFPAC-1 cells (Fig. 3D) is different to that observed for $\mathrm{MCF}-7$ and LNCaP cells (Fig. 3A).

Examining SK-N-MC cells, p21 was markedly expressed in untreated control cells (Fig. 3E). Following incubation with 311 or Dp44mT, there was a slight, but not significant $(p>0.05)$ decrease in $\mathrm{p} 21$ protein levels in comparison to control cells, while DFO exerted no significant effect (Fig. 3E). In addition, incubation with DNA-damaging agents resulted in no significant $(p>0.05)$ change in $\mathrm{p} 21$ protein expression relative to the control in SK-N-MC cells (Fig. 3E), which was expected considering that these cells are p53 null [69]. In contrast to the results with the other cell-types, the results in terms of $\mathrm{p} 21$ protein expression obtained with SK-N-MC cells varied between investigations. For instance, during the current study, incubation with chelators resulted in a consistently slight, but not significant $(p>0.05)$ decrease in $\mathrm{p} 21$ expression in SK-N-MC cells over 6 experiments (Fig. 3E). On the other hand, several previous investigations reported a slight increase of p21 protein relative to the control [9], or significant up-regulation [72]. This variability in response of p21 to the agents was only observed for SK-N-MC cells and may be related to clonal differences in tumor cell lines that occur as a function of passage number [73].

Considering that the metastasis suppressor NDRG1 was found to up-regulate p21 expression in a wide variety of cancer cells [41], we further examined the levels of NDRG1 in response to the Fe chelators and DNA damaging agents in each of the five cell lines. As previously reported [25], two NDRG1 bands at 43- and 44-kDa were detected in all cell lines examined (Fig. 3A-3E). These bands may correspond to different post-translational modifications e.g., truncation and phosphorylation states of NDRG1 [74, 75]. Hence, the densitometric analysis performed for NDRG1 herein represents the sum of the two bands. As shown in Fig. 3A-3D, NDRG1 protein levels were significantly $(p<0.01-0.05)$ increased in MCF-7, LNCaP, SK-MEL-28 and CFPAC-1 cells after incubation with the chelators. A slight, but not significant $(p>0.05)$ increase in NDRG1 was also observed in SK-N-MC cells following incubation with these ligands. However, only in SK-MEL-28 (Fig. 3C) and CFPAC-1 cells (Fig. 3D) did the expression of NDRG1 directly correlate with increased p21 levels after incubation with these latter agents. No significant $(p>0.05)$ alterations in the expression of NDRG1 protein levels were detected after incubation with the DNAdamaging agents relative to the control in all cell-types (Fig. 3A-3E).

Since p53 plays an important role in sensing both nutrient-depletion and DNA-damage [11, 76, 77], and can directly influence p21 expression [40], the difference in the

\section{Table 1: A summary of p21 mRNA and protein expression in response to Fe chelators or DNA-damaging agents.}

\begin{tabular}{|c|c|c|c|c|c|c|c|}
\hline \multirow[t]{2}{*}{ p53 status } & \multirow[t]{2}{*}{ Cell line } & \multicolumn{2}{|c|}{ Untreated Control } & \multicolumn{2}{|c|}{$\begin{array}{c}\text { General effect of Fe } \\
\text { Chelators }\end{array}$} & \multicolumn{2}{|c|}{$\begin{array}{l}\text { General effect of DNA- } \\
\text { damaging agents }\end{array}$} \\
\hline & & p21 mRNA & p21 protein & p21 mRNA & p21 protein & p21 mRNA & p21 protein \\
\hline \multirow[t]{2}{*}{ WT p53 ${ }^{1-3}$} & MCF-7 & Little expression & + & + & - & + & $+* *$ \\
\hline & $\mathrm{LNCaP}$ & Little expression & + & + & $\begin{array}{l}\text { No change } \\
\text { vs. Control }\end{array}$ & + & + \\
\hline \multirow[t]{2}{*}{ Mutant p53 ${ }^{1,4}$} & SK-MEL-28 & Little expression & $\begin{array}{c}\text { No } \\
\text { expression }\end{array}$ & + & + & $+*$ & No expression \\
\hline & CFPAC-1 & Little expression & + & + & + & $+*$ & $\begin{array}{l}\text { No change vs. } \\
\text { Control }\end{array}$ \\
\hline p53 Null $^{5}$ & SK-N-MC & No expression & + & + & $\begin{array}{l}\text { No change } \\
\text { vs. Control }\end{array}$ & + & $\begin{array}{l}\text { No change vs. } \\
\text { Control }\end{array}$ \\
\hline
\end{tabular}

${ }^{1} \mathrm{O}^{\prime}$ Connor et. al. Cancer Res. 1997; 57: 4285-4300.

${ }^{2}$ Wosikowski et. al. Cell Growth Differ. 1995; 6: 1395-1403.

${ }^{3}$ Jackson et. al. Urol Oncol. 2002; 7: 99-104.

${ }^{4}$ Redston et. al. Cancer Res. 1994; 54: 3025-3033.

${ }^{5}$ Moll et. al. Mol Cell Biol. 1996; 16: 1126-1137.

"Unlike CP and MC, Act D did not increase p21 mRNA in these cell lines relative to the control (Fig. 2C and 2D).

** Unlike Act D and CP, MC significantly decreased p21 protein levels in this cell line relative to the control (Fig. 3A). 
response of $\mathrm{p} 21$ protein expression to chelators and DNAdamaging agents was hypothesized to be due to differences in p53 status between the cell-types (Table 1). However, collectively, assessing all cell-types examined, increased p21 mRNA and protein expression after incubation with chelators was not positively correlated to WT p53 status (Table 1). This conclusion is clear when comparing the effect of chelators on MCF-7 cells and SK-MEL-28 cells (Fig. 3A, 3C). In fact, MCF-7 cells have WT p53 and demonstrated a decrease in $\mathrm{p} 21$ protein after incubation with chelators (Fig. 3A; Table 1), while SK-MEL-28 cells are p53 mutant and showed a marked increase in p21 protein after treatment with these agents (Fig. 3C; Table 1).

It should be noted that the three chelators used in this investigation increased $p 21 \mathrm{mRNA}$ levels in all celltypes examined (Fig. 2A-2E). In contrast, the protein levels were significantly $(p<0.01-0.05)$ decreased by these agents in MCF-7 cells (Fig. 3A). These observations suggest that p21 translation may be inhibited, or alternatively, there may be increased p21 protein degradation in this cell-type. Indeed, inhibition of protein synthesis is known to occur after incubation of cells with chelators, including DFO and 311 [21].

\section{The expression of the MDM2 oncoprotein in response to chelators may affect expression of p21}

As p53 status between the cell-types examined did not satisfactorily explain the different $\mathrm{p} 21$ response to the chelators, further studies were performed to determine the molecular mechanisms involved. Considering this, studies then assessed MDM2, which functions as an oncoprotein and a negative regulator of both p53 and p21 [56, 57, 63, 64]. Interestingly, MDM 2 has also been shown to promote p21 protein degradation independently of its effects on p53 $[56,57]$. Hence, the following investigation focused on the effect of the agents on MDM2 expression (Fig. 4A-3D). Numerous isoforms of MDM2 are known to exist (i.e., full-length $\mathrm{p} 90^{\mathrm{MDM} 2}, \mathrm{p} 75^{\mathrm{MDM} 2}, \mathrm{p} 60^{\mathrm{MDM} 2}, \mathrm{p} 50^{\mathrm{MDM} 2}$, etc.), each having various effects on its downstream targets [78, 79]. Two particular isoforms, namely $\mathrm{p} 90^{\mathrm{MDM} 2}$ and $\mathrm{p} 75^{\mathrm{MDM} 2}$, have been reported to predominate in both human and murine cells $[80,81]$. The over-expression of $\mathrm{p} 75^{\mathrm{MDM} 2}$, which cannot bind to $\mathrm{p} 53$, has been found to interfere with the ability of $\mathrm{p} 90^{\mathrm{MDM} 2}$ to promote $\mathrm{p} 53$ degradation [62]. Hence, the effects of the agents on these two latter isoforms were particularly important to assess.
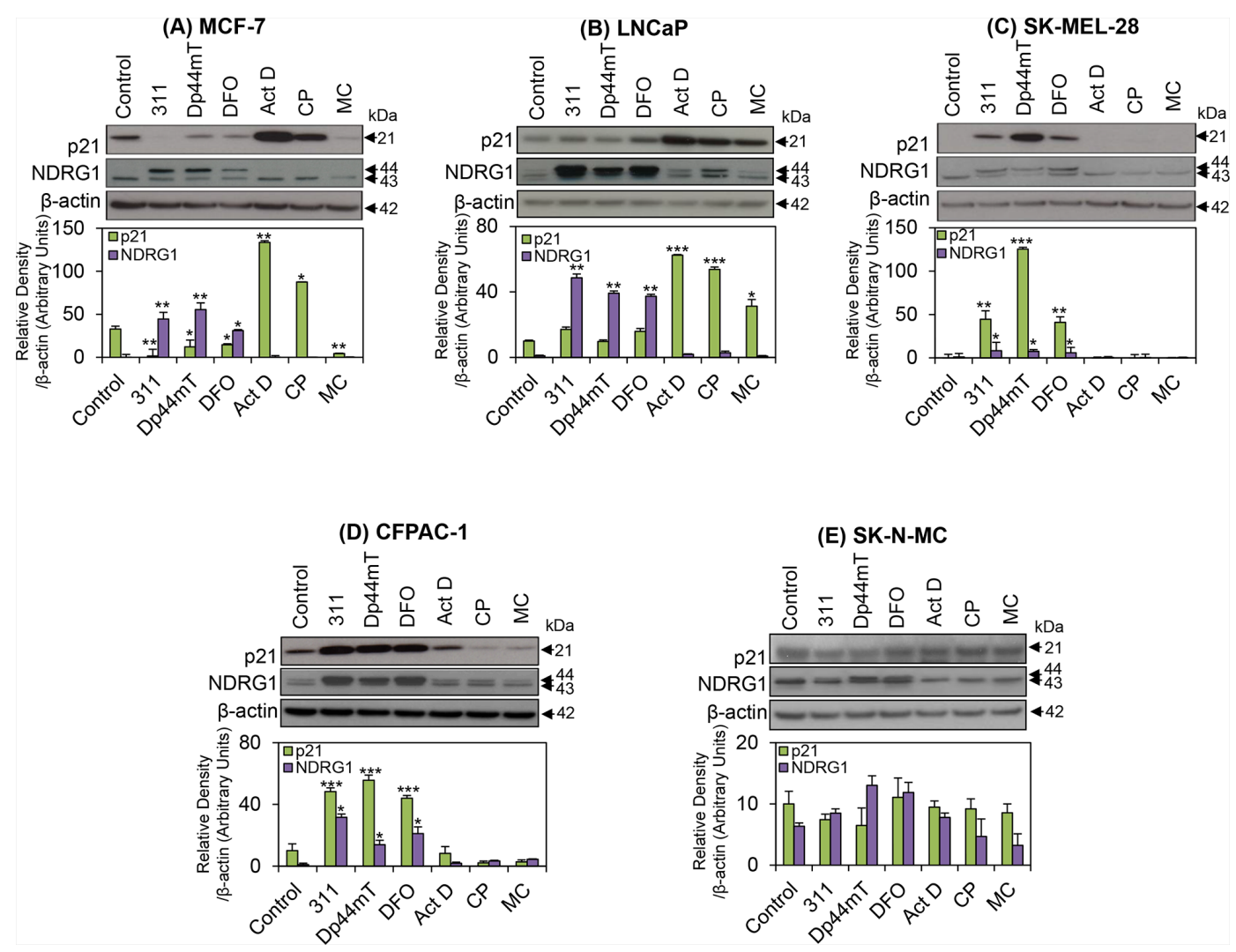

Figure 3: The effect of the chelators 311, Dp44mT, or DFO, and the DNA-damaging agents, Act D, CP or MC on p21 or NDRG1 protein levels in five different tumor cell lines. A. MCF-7; B. LNCaP; C. SK-MEL-28; D. CFPAC-1; and E. SK-N$\mathrm{MC}$ cells. Cells were incubated for $24 \mathrm{~h} / 37^{\circ} \mathrm{C}$ with the chelators, $311(25 \mu \mathrm{M})$, Dp44mT $(2.5 \mu \mathrm{M})$, DFO $(250 \mu \mathrm{M})$, or the DNA-damaging agents, Act D $(5 \mathrm{nM}), \mathrm{CP}(20 \mu \mathrm{M})$, or $\mathrm{MC}(30 \mu \mathrm{M})$. The blots are typical of 3-6 independent experiments, while the densitometric analysis is mean $\pm \mathrm{SD}$ (3-6 experiments). Relative to control: ${ }^{*} p<0.05, * * p<0.01,{ }^{* * *} p<0.001$. 

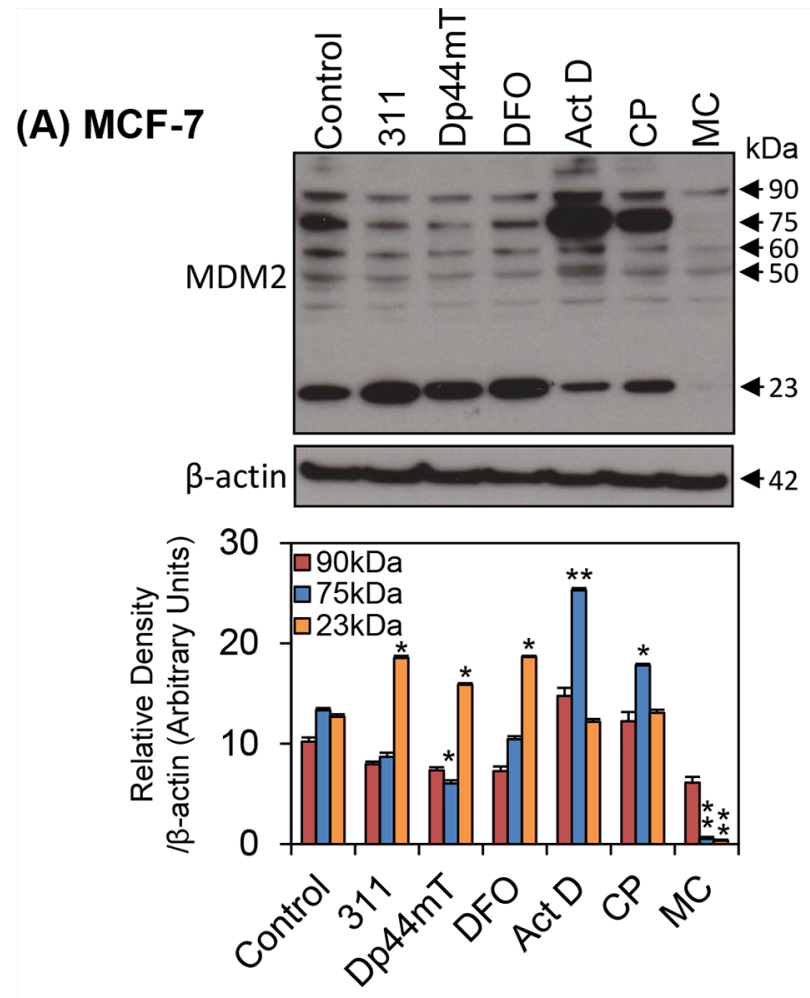

(C) SK-MEL-28 仓ั
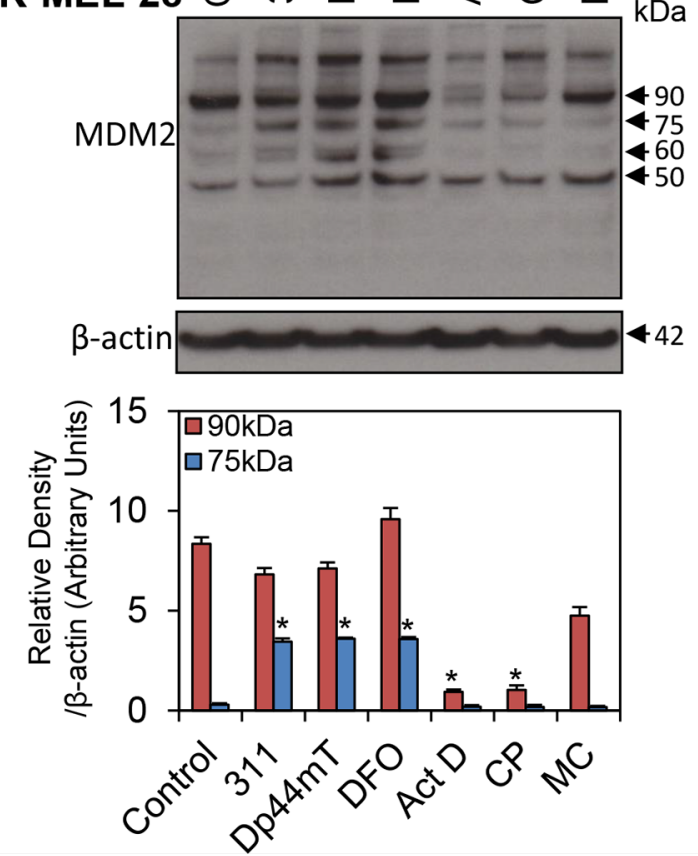

(B) LNCaP

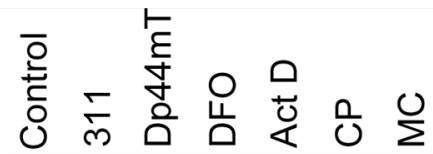

MDM2

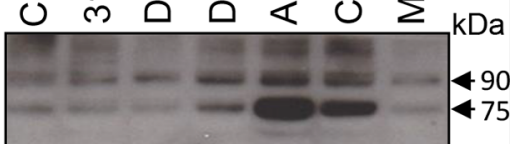

(D) SK-N-MC

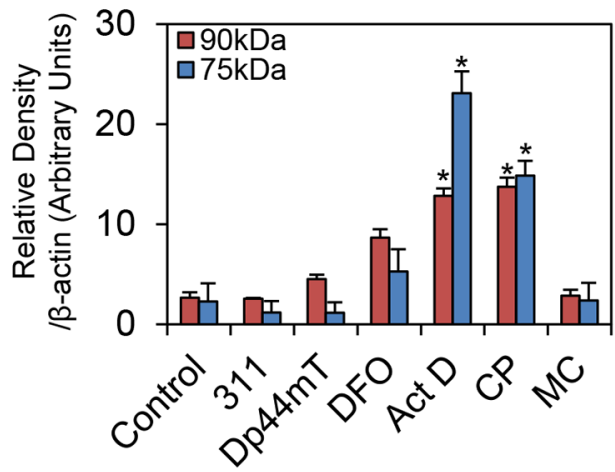

MDM2

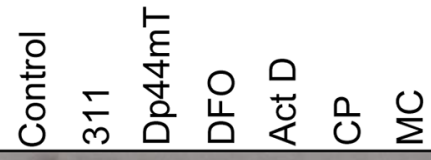

$k \mathrm{Da}$
+90
+75
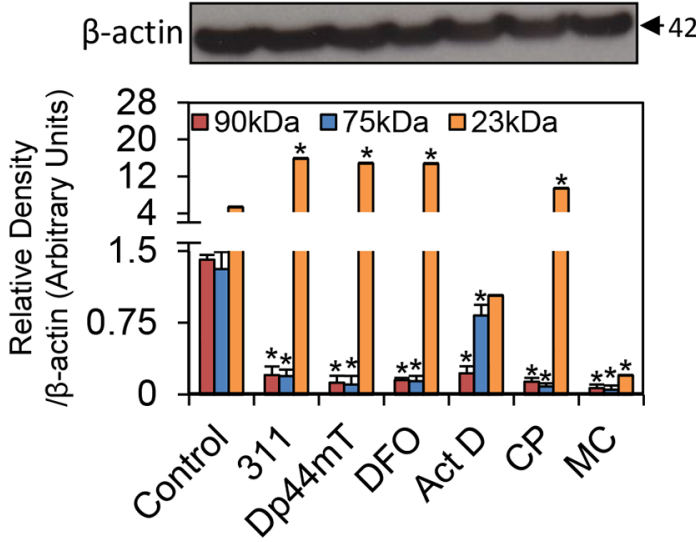

Figure 4: The effect of the chelators 311, Dp44mT, or DFO, and the DNA-damaging agents, Act D, CP or MC on MDM2 protein isoforms in four different tumor cell lines. A. MCF-7; B. LNCaP; C. SK-MEL-28; and D. SK-N-MC cells. Cells were incubated for $24 \mathrm{~h} / 37^{\circ} \mathrm{C}$ with the chelators, $311(25 \mu \mathrm{M})$, Dp44mT $(2.5 \mu \mathrm{M})$, DFO $(250 \mu \mathrm{M})$, or the DNA-damaging agents, Act D $(5 \mathrm{nM}), \mathrm{CP}(20 \mu \mathrm{M})$, or MC $(30 \mu \mathrm{M})$. The blots are typical of 3 independent experiments, while the densitometric analysis is mean $\pm \mathrm{SD}$ (3 experiments). Relative to control: ${ }^{*} p<0.05,{ }^{* *} p<0.01,{ }^{* * *} p<0.001$. 
First, it is important to note that despite exhaustive attempts, western blot analysis revealed that of the five cell-types used, MDM2 isoforms were not detected in CFPAC-1 cells. This was in direct contrast to the other cell lines examined, and hence, only MDM2 blots for MCF-7 (Fig. 4A), LNCaP (Fig. 4B), SK-MEL-28 (Fig. 4C) and SK-N-MC cells (Fig. 4D) are shown. After incubation of MCF-7 cells with chelators, the expression of multiple isoforms of MDM2 was slightly, but not significantly $(p>0.05)$ decreased in comparison to the control cells. These included the $\mathrm{p} 50^{\mathrm{MDM} 2}, \mathrm{p} 60^{\mathrm{MDM} 2}$ and $\mathrm{p} 90^{\mathrm{MDM} 2}$ isoforms (Fig. 4A). On the other hand, incubation of these cells with Dp44mT demonstrated a significant $(p<0.05)$ decrease in the expression of the $\mathrm{p} 75^{\mathrm{MDM} 2}$ isoform. In contrast, incubation with Act $\mathrm{D}$ or $\mathrm{CP}$ resulted in a significant $(p<0.01-0.05)$ increase in the expression of the $\mathrm{p} 75^{\mathrm{MDM} 2}$ isoform (Fig. 4A). However, MC significantly $(p<0.01)$ decreased the expression of the $\mathrm{p} 75^{\mathrm{MDM} 2}$ band. Of relevance, the expression pattern of $\mathrm{p} 75^{\mathrm{MDM} 2}$ was similar to that observed for $\mathrm{p} 21$ protein in this cell-type (Fig. 3A). Considering this relative to the ability of $\mathrm{p} 75^{\mathrm{MDM} 2}$ to inhibit the function of $\mathrm{p} 90^{\mathrm{MDM} 2}$ [62] to promote p21 degradation [56, 57], lower levels of $\mathrm{p} 75^{\mathrm{MDM} 2}$ relative to the control would, in theory, promote lower $\mathrm{p} 21$ protein levels in MCF-7 cells, as shown in Fig. 3A.

A prominent band at approximately $23 \mathrm{kDa}$ was also detected with the MDM2 antibody in MCF-7 cells (Fig. 4A), but does not correlate to any previously reported MDM2 isoform [78], and its functional significance remains unclear. Incubation of cells with chelators significantly $(p<0.05)$ increased expression of the $23 \mathrm{kDa}$ band, whereas treatment with the DNAdamaging agent $\mathrm{MC}$ significantly $(p<0.01)$ reduced its expression (Fig. 4A). Considering these latter observations, this low $M_{r}$ band could potentially be a cleaved product of full-length $\mathrm{p} 90^{\mathrm{MDM} 2}$, or its shorter isoforms. Notably, this $23 \mathrm{kDa}$ band was consistently detected only in MCF-7 cells (Fig. 4A) and SK-N-MC cells (Fig. 4D), but not the other cell lines, indicating its expression was cell-type specific.

Assessing LNCaP cells, only the p75 $5^{\mathrm{MDM} 2}$ and p90 ${ }^{\mathrm{MDM} 2}$ isoforms were apparent (Fig. 4B). Densitometric analysis demonstrated that over 3 experiments, 311 and Dp44mT had no significant $(p>0.05)$ effect on the expression of both $\mathrm{p} 75^{\mathrm{MDM} 2}$ and $\mathrm{p} 90^{\mathrm{MDM} 2}$, while $\mathrm{DFO}$ caused a slight, but not significant $(p>0.05)$ increase in the expression of these isoforms relative to the control (Fig. 4B). The response of these isoforms to DNAdamaging agents in LNCaP cells (Fig. 4B) was similar to that found for MCF-7 cells (Fig. 4A), there being a significant $(p<0.05)$ increase in the $\mathrm{p} 75^{\mathrm{MDM} 2}$ and $\mathrm{p} 90^{\mathrm{MDM} 2}$ isoforms in response to the DNA-damaging agents, Act D and $\mathrm{CP}$. On the other hand, MC had little effect relative to the control in LNCaP cells (Fig. 4B). It is evident that the expression patterns of the proteins, p21 (Fig. 3B) and p75 ${ }^{\mathrm{MDM} 2}$ (Fig. 4B), was similar in LNCaP cells incubated with chelators, or the DNA-damaging agents, Act D or CP. Notably, a band above $90 \mathrm{kDa}$ was also found in this cell-type (Fig. 4B), but does not correlate to any previously reported MDM2 isoforms [78], and was not consistently observed. Therefore, it may be attributed to non-specific binding of the MDM2 antibody. Furthermore, a band which appeared at approximately $37 \mathrm{kDa}$ (Fig. 4B) was not always observed in repeat studies, and thus, was not considered further.

Four MDM2 isoforms were identified in SKMEL-28 cells, namely p50 ${ }^{\mathrm{MDM} 2}$, p60 ${ }^{\mathrm{MDM} 2}$, p $75^{\mathrm{MDM} 2}$ and p90 ${ }^{\mathrm{MDM} 2}$ (Fig. 4C). Incubation of SK-MEL-28 cells with all chelators led to a significant $(p<0.05)$ increase in $\mathrm{p} 75^{\mathrm{MDM} 2}$ relative to the control. This expression pattern was similar to that observed for p21 in this cell-type (Fig. 3C). On the other hand, the expression of $\mathrm{p} 50^{\mathrm{MDM} 2}$, p $60^{\mathrm{MDM} 2}$ or $\mathrm{p} 90^{\mathrm{MDM} 2}$ was not affected by the chelators in these cells when compared to untreated controls (Fig. 4C). Incubation of these cells with DNA-damaging agents led to no significant $(p>0.05)$ alterations in the levels of $\mathrm{p} 50^{\mathrm{MDM} 2}, \mathrm{p} 60^{\mathrm{MDM} 2}$ or $\mathrm{p} 75^{\mathrm{MDM} 2}$. In contrast, following Act D and $\mathrm{CP}$ treatment, there was a significant $(p<0.05)$ reduction in the expression of the $\mathrm{p} 90^{\mathrm{MDM} 2}$ isoform. Once again, a non-specific band above $90 \mathrm{kDa}$ was detected.

Examining SK-N-MC cells, both the p75 MDM2 and $\mathrm{p} 90^{\mathrm{MDM} 2}$ isoforms were detected (Fig. 4D). A band correlating with $\mathrm{p} 60^{\mathrm{MDM} 2}$ was inconsistently observed in the blots for this cell line, and therefore, is not discussed further. There was a significant $(p<0.05)$ decrease in the expression of both the $\mathrm{p} 75^{\mathrm{MDM} 2}$ and $\mathrm{p} 90^{\mathrm{MDM} 2}$ isoforms after incubation of SK-N-MC cells with chelators and DNA-damaging agents relative to the control. However, the p21 levels were not significantly altered in response to chelators or DNA-damaging agents in this cell line (Fig. 3E). This lack of effect on p21 expression could be due to $\mathrm{p} 75^{\mathrm{MDM} 2}$ (that may protect $\mathrm{p} 21$ from degradation) and $\mathrm{p} 90^{\mathrm{MDM} 2}$ (that degrades $\mathrm{p} 21 ;[56,57]$ ) being both significantly $(p<0.05)$ reduced to approximately the same extent (Fig. 4D). In addition, as found in MCF-7 cells (Fig. 4A), a $23 \mathrm{kDa}$ band was also identified in SK-N-MC cells (Fig. 4D). As similarly observed for MCF-7 cells, a significant $(p<0.05)$ increase in the $23 \mathrm{kDa}$ band was observed in these cells when incubated with chelators and $\mathrm{CP}$, whereas a significant $(p<0.05)$ decrease was found after incubation with MC (Fig. 4D).

Overall, there was a close correlation between the expression of $\mathrm{p} 21$ and the $\mathrm{p} 75^{\mathrm{MDM} 2}$ isoform in response to $\mathrm{Fe}$ chelators in three of the cell-types investigated (i.e., MCF-7 $(r=+0.92)$, LNCaP $(r=+0.92)$ and SKMEL-28 $(r=+0.81))$. This observation suggested that one mechanism by which chelators may regulate $\mathrm{p} 21$ expression could potentially occur through regulating the expression of $\mathrm{p} 75^{\mathrm{MDM} 2}$. However, MDM2 expression did not explain the response of the CFPAC-1 cells to chelators and DNA-damage, as this protein was not detected in this cell line. Hence, further experiments were conducted to 
examine the expression of another potential regulator of p21, namely $\Delta \mathrm{Np} 63$.

\section{Expression of $\Delta \mathrm{Np} 63$ is not altered by chelators or DNA-damaging agents in all cell-types investigated}

The $p 63$ gene is a member of the $p 53$ gene family $[82,83]$. It encodes multiple isoforms of $p 63$ with a variety of functions, some of which have been shown to transactivate $\mathrm{p} 53$ target genes, including $p 21$ [84]. However, the $\Delta \mathrm{Np} 63$ isoform lacks the transactivation domain and can act as a dominant negative regulator to inhibit transactivation by $\mathrm{p} 53$ and $\mathrm{p} 63$, leading to inhibition of target gene (e.g., p21) expression [60, 85, 86]. The over-expression of the $\Delta \mathrm{Np} 63$ isoform has previously been reported as a negative regulator of cyclindependent kinase inhibitors [59], including p21 [58,61]. Hence, $\Delta$ Np63 expression in response to the chelators was examined using an antibody specific for this particular isoform to determine if it was involved in the response of p21 to these agents (Fig. 3A-3E). Considering this, western blot analysis was used to assess the potential role of $\Delta \mathrm{Np} 63$ in regulating p21 levels in all cell-types examined herein (i.e., MCF-7, LNCaP, SK-MEL-28, CFPAC-1 and SK-N-MC).

Two $\triangle \mathrm{Np} 63$ bands were detected at approximately $63 \mathrm{kDa}$ and $74 \mathrm{kDa}$ in all cell lines assessed (Fig. Supplemental 1). These two bands have been previously reported as different isoforms of $\Delta \mathrm{Np} 63$ [87, 88]. Densitometric analysis indicated that incubation with chelators or DNA-damaging agents had no significant $(p>0.05)$ effect on the expression of either the 63 or $74 \mathrm{kDa}$ bands (Fig. Supplemental 1), this suggested that the alterations in p21 observed in these cell-types were independent of $\Delta \mathrm{Np} 63$ expression.

\section{Nuclear localization of p21 following intracellular chelation and DNA-damage}

Next, considering that the nuclear localization of p21 is crucial for its inhibitory function [45], cytoplasmic and nuclear fractionation studies were conducted to assess the intracellular location of the p21 protein following incubation of cells with chelators or DNA-damaging agents (Fig. 5A-5E). Histone deacetylase 1 (HDAC1) was also assessed to check the purity of the nuclear fractions and was shown to be appropriate in all experiments (Fig. 5A-5E).

Examination of MCF-7 cells incubated with control medium alone demonstrated that there was markedly and significantly $(p<0.01)$ greater p21 levels in the nuclear $(\mathrm{N})$ fraction as compared to the cytoplasmic $(\mathrm{C})$ fraction (Fig. 5A). Moreover, relative to the control, nuclear $\mathrm{p} 21$ levels were significantly $(p<0.001-0.05)$ reduced by all chelators, while cytoplasmic p 21 was not significantly ( $p>0.05$ ) altered by these agents (Fig. 5A). This observation reflects the reduction in total p21 protein levels observed previously relative to the control (Fig. 3A). The decrease of nuclear p21 in response to these chelators is consistent with previous studies in this cell line [71]. Assessing MCF-7 cells treated with Act $\mathrm{D}$, there was a significant $(p<0.001-0.05)$ increase in $\mathrm{p} 21$ protein present in both cytoplasmic and nuclear fractions relative to the control (Fig. 5A). Cells incubated with $\mathrm{CP}$ demonstrated a significant $(p<0.05)$ increase in cytoplasmic, but not nuclear $\mathrm{p} 21$, when compared to the controls. In contrast to Act D and $\mathrm{CP}$, incubation with $\mathrm{MC}$ led to a significant $(p<0.01)$ decrease in nuclear levels of p21 relative to the control (Fig. 5A). This finding was consistent with the effects of $\mathrm{MC}$ on total $\mathrm{p} 21$ protein expression (Fig. 3A).

In contrast to MCF-7 cells (Fig. 5A), untreated LNCaP cells expressed p21 at approximately equal levels in both the cytoplasm and nucleus (Fig. 5B). Moreover, following incubation of these cells with $311, \mathrm{Dp} 44 \mathrm{mT}$ or DFO, there was no significant $(p>0.05)$ change in nuclear or cytoplasmic p21 levels, which is in agreement with the total p21 levels (Fig. 3B). On the other hand, a significant $(p<0.001-0.05)$ up-regulation of $\mathrm{p} 21$ in both the cytoplasm and nucleus was observed in $\mathrm{LNCaP}$ cells incubated with all DNA-damaging agents (Fig. 5B) that was also in correlation with total p21 expression (Fig. 3B).

Of all the cell lines utilized, SK-MEL-28 was the only cell line, which had no detectable p21 expression in the control cytosolic or nuclear fractions (Fig. 5C). However, following incubation of these cells with 311 or DFO, nuclear $\mathrm{p} 21$ was significantly $(p<0.01-0.05)$ increased, while cytoplasmic p21 levels were not markedly affected. On the other hand, SK-MEL-28 cells incubated with Dp44mT demonstrated significantly $(p<0.001-0.01)$ higher levels of $\mathrm{p} 21$ protein in both the cytoplasmic and nuclear fractions relative to the control (Fig. 5C). The DNA-damaging agents did not significantly $(p>0.05)$ affect p21 expression in the cytoplasmic or nuclear fractions of this cell line. These data were in agreement with total p21 levels (Fig. 3C).

In CFPAC-1 cells incubated with control medium alone, $\mathrm{p} 21$ expression was greater, but not significantly $(p>0.05)$ different in the nuclear fraction relative to the cytoplasmic fraction (Fig. 5D). As observed with total p21 levels (Fig. 3D), when CFPAC-1 cells were incubated with chelators, there was a significant $(p<0.01)$ increase in p21 protein levels in both the cytoplasmic and nuclear fractions compared with the controls. In contrast, after incubation with DNA-damaging agents, there was no significant $(p>0.05)$ change in cytoplasmic or nuclear p21 levels.

Data obtained from SK-N-MC cells showed relatively equal amounts of p21 in both the cytoplasmic and nuclear fractions, regardless of chelator treatment (Fig. 5E). Furthermore, no significant $(p>0.05)$ alterations 


\section{(A) MCF-7}

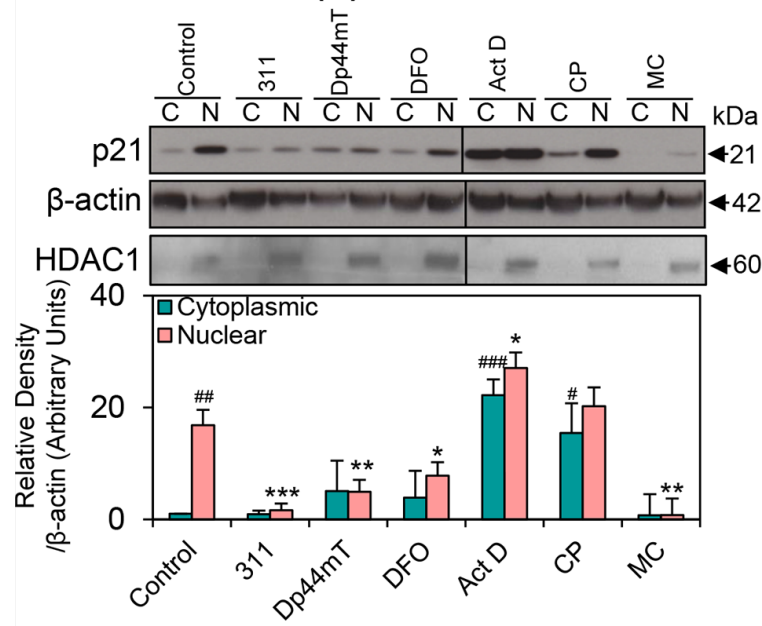

(C) SK-MEL-28

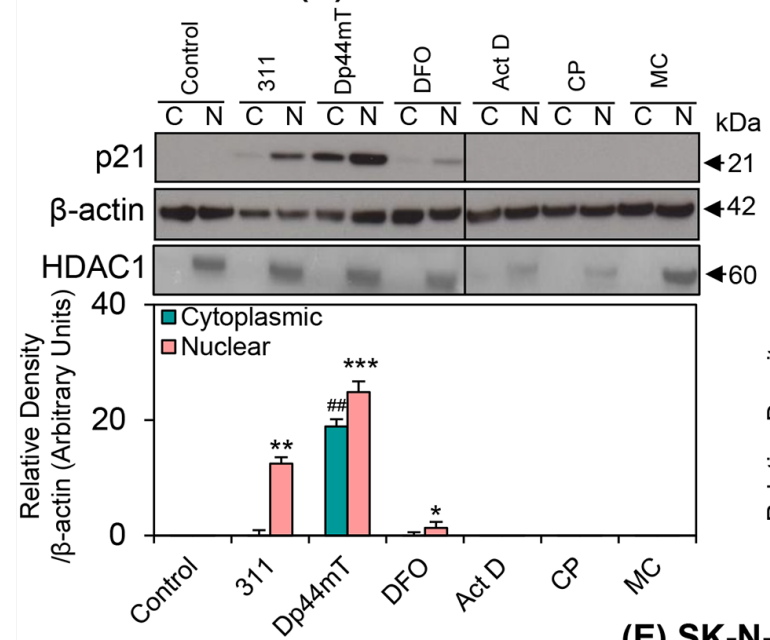

(B) LNCaP

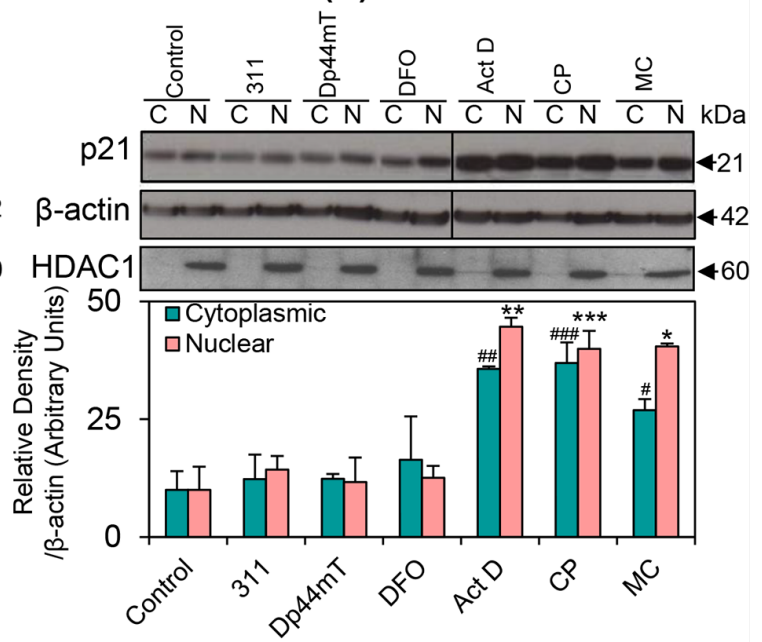

(D) CFPAC-1

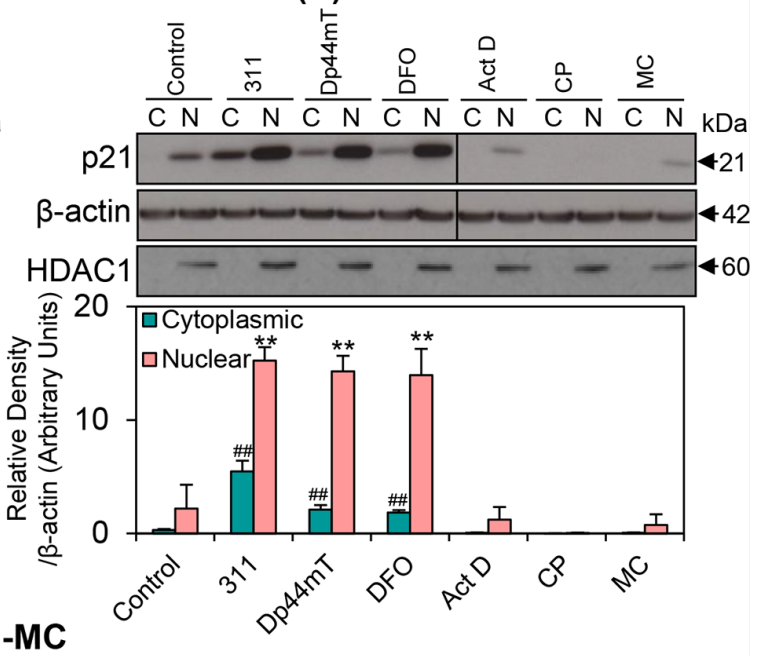

(E) SK-N-MC

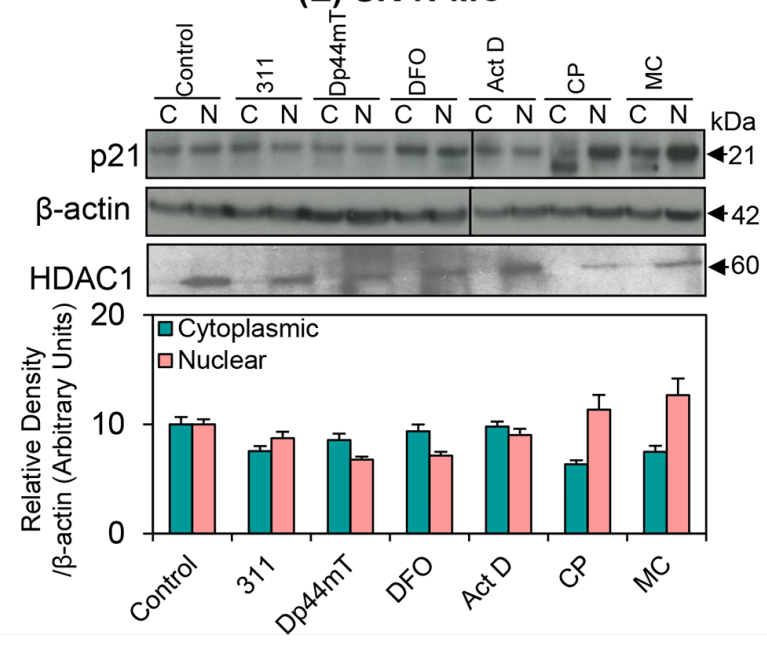

Figure 5: The effect of the chelators 311, Dp44mT, or DFO, and the DNA-damaging agents, Act D, CP or MC on the cytoplasmic and nuclear expression of p21 in five different tumor cell lines. A. MCF-7; B. LNCaP; C. SK-MEL-28; D. CFPAC-1; and E. SK-N-MC cells. Cells were incubated for $24 \mathrm{~h} / 37^{\circ} \mathrm{C}$ with the chelators, $311(25 \mu \mathrm{M})$, Dp $44 \mathrm{mT}(2.5 \mu \mathrm{M})$, DFO $(250 \mu \mathrm{M})$, or the DNA-damaging agents, Act D $(5 \mathrm{nM}), \mathrm{CP}(20 \mu \mathrm{M})$, or MC $(30 \mu \mathrm{M})$. A vertical line appears on some blots to indicate the use of two gels. Indeed, in some experiments, due to hardware constraints, samples from one experiment were required to be run on 2 gels at the same time. These were then exposed equally under exactly the same conditions at the same time. The blots are typical of 3-6 independent experiments, while the densitometric analysis is mean $\pm \mathrm{SD}$ (3-6 experiments). Relative to untreated control (cytoplasmic fraction): $\# p<0.05, \# \# p<0.01, \# \# p<0.001$. Relative to untreated control (nuclear fraction): ${ }^{*} p<0.05,{ }^{* *} p<0.01,{ }^{* * *} p<0.001$. 
were observed with the DNA-damaging agents compared to the untreated control (Fig. 5E) in correlation with the total p21 levels (Fig. 3E).

Immunofluorescence studies were then conducted to further assess the cellular distribution of $\mathrm{p} 21$ in the MCF-7 and SK-MEL-28 cell lines (Fig. 6A-6B). These two cell lines were chosen as the focus for these experiments because of their distinct expression of p21 protein in response to Fe chelator treatment, namely a reduction in MCF-7 cells (Figs. 3A, 5A) and an increase in SK-MEL-28 cells (Figs. 3C, 5C). Fig. 6A confirms that the overall levels of p21 in the MCF-7 cell line decrease upon treatment with chelators. These results also demonstrate the increased levels and accumulation of p21 in the nucleus of MCF-7 cells incubated with the DNA-damaging agents, Act D and CP, which was in agreement with the fractionation results in Fig. 5A. On the other hand, there was a marked decrease in the intensity of p21 expression after incubation with MC (Fig. 6A) and this was consistent with the western analysis (Fig. 3A, 5A). In agreement with the fractionation results (Fig. 5C), immunofluorescence studies demonstrated nuclear accumulation of p21 in SK-MEL-28 cells in response to the chelators, but not in cells treated with the DNA-damaging agents. In summary, there was a marked difference in the expression levels and cellular distribution of p21 depending upon the cell-type examined and also the response of these cells to the chelators.

\section{DISCUSSION}

It has been reported that some cancer cells have elevated p21 levels, while maintaining the ability to rapidly proliferate [89-91]. In fact, cytoplasmic p21 expression is common in human malignancies and correlates positively with aggressive tumors and poor prognosis [92-94]. Considering that $\mathrm{Fe}$ is a new metabolic target for inhibiting cancer cell proliferation, with several Fe chelators already entering clinical trials $[9,15,16]$, we assessed the effect of three of these agents compared to DNA damaging agents on p21 expression. This is important because $\mathrm{Fe}$ is known to be involved in the progression of cells through the cell cycle by influencing the expression of a variety of molecules involved in cell cycle control, such as p21 and p53 [8-11]. These studies were conducted in five different cancer cell lines, two of which were expressing wild-type p53 (MCF-7 and LNCaP); two expressing mutant forms of p53 (SKMEL-28 and CFPAC-1); and one cell line that was p53 null (SK-N-MC; Table 1) [65-69].

Initial experiments demonstrated that chelators were able to markedly up-regulate $p 21 \mathrm{mRNA}$ levels, in all of the cell-types examined (Fig. 2A-2E), regardless of their p53 status. However, the expression of p21 protein in response to chelator treatment did not correspond to its mRNA levels in all cell lines examined. In fact, incubation of cells with chelators resulted in decreased total p21 protein in MCF-7 cells (Fig. 3A), whereas there was an increase in p21 expression in SK-MEL-28 (Fig. 3C) and CFPAC-1 cells (Fig. 3D). On the other hand, there was no significant change in p21 protein levels after incubation of LNCaP or SK-N-MC cells with the chelators (Fig. 3B, 3E).

Despite that both MCF-7 and LNCaP cells have wild-type p53 expression (Table 1), their responses to chelators were markedly different, with MCF-7 cells having reduced p21 expression, while there was no significant change in total p21 protein in LNCaP cells. This observation indicates that the effect of chelators on p21 expression may not involve p53 and could be occurring through other mechanisms. This was further demonstrated by examining CFPAC-1 and SK-MEL-28 cells, where the chelators were able to markedly increase p21 levels (Fig. 3C, 3D), despite both these cells having mutated p53 (Table 1). Collectively, these data suggest that the chelator-induced regulation of $\mathrm{p} 21$ does not correlate with p53 status and is cell line-dependent.

In contrast to $\mathrm{p} 21$ protein levels, p21 mRNA expression was consistently increased in each of the cell lines examined in response to chelation (Fig. 2A-2E). This indicates that $\mathrm{p} 21$ translation may potentially be inhibited in some of these cells and warrants further investigation. Alternatively, p21 could be regulated at the post-transcriptional level by protein degradation [95]. In fact, $\mathrm{Fu}$ and Richardson [70] examined the downregulation of $\mathrm{p} 21$ following Fe-depletion in MCF-7 cells and demonstrated that it was due to: (1) inhibited translocation of $p 21 \mathrm{mRNA}$ from the nucleus to cytosolic translational machinery; and (2) induction of ubiquitinindependent proteasomal degradation. Whether any of these mechanisms are responsible for the failure of the increased $p 21 \mathrm{mRNA}$ to be translated to protein in $\mathrm{LNCaP}$ and SK-N-MC cells after incubation with chelators is not known.

Upon treatment of the five cell-types assessed herein with DNA-damaging agents, p21 mRNA expression was significantly up-regulated in all cell lines examined, except after incubation of SK-MEL-28 and CFPAC-1 cells with Act D (Fig. 2A-2E). The increase in p21 mRNA levels occurred irrespective of p53 status and suggested that the DNA-damaging agents could up-regulate $p 21$ mRNA by a $\mathrm{p} 53$-independent mechanism. A paradoxical increase of p21 mRNA (Fig. 2A) and decrease in protein expression (Fig. 3A) was observed in response to the DNA-damaging agent, $\mathrm{MC}$, in MCF-7 cells. This trend was also observed after incubation of SK-MEL-28 and CFPAC-1 cells with $\mathrm{CP}$ or $\mathrm{MC}$ (Fig. 2C, $2 \mathrm{D}$ and $3 \mathrm{C}, 3 \mathrm{D})$. In the case of $\mathrm{MC}$, it has been reported that this agent also inhibits the transcription of ribosomal RNA, which could significantly decrease protein translation in MCF-7 cells [96] and may explain the decreased p21 protein levels observed with this agent. 


\section{(A) MCF-7}

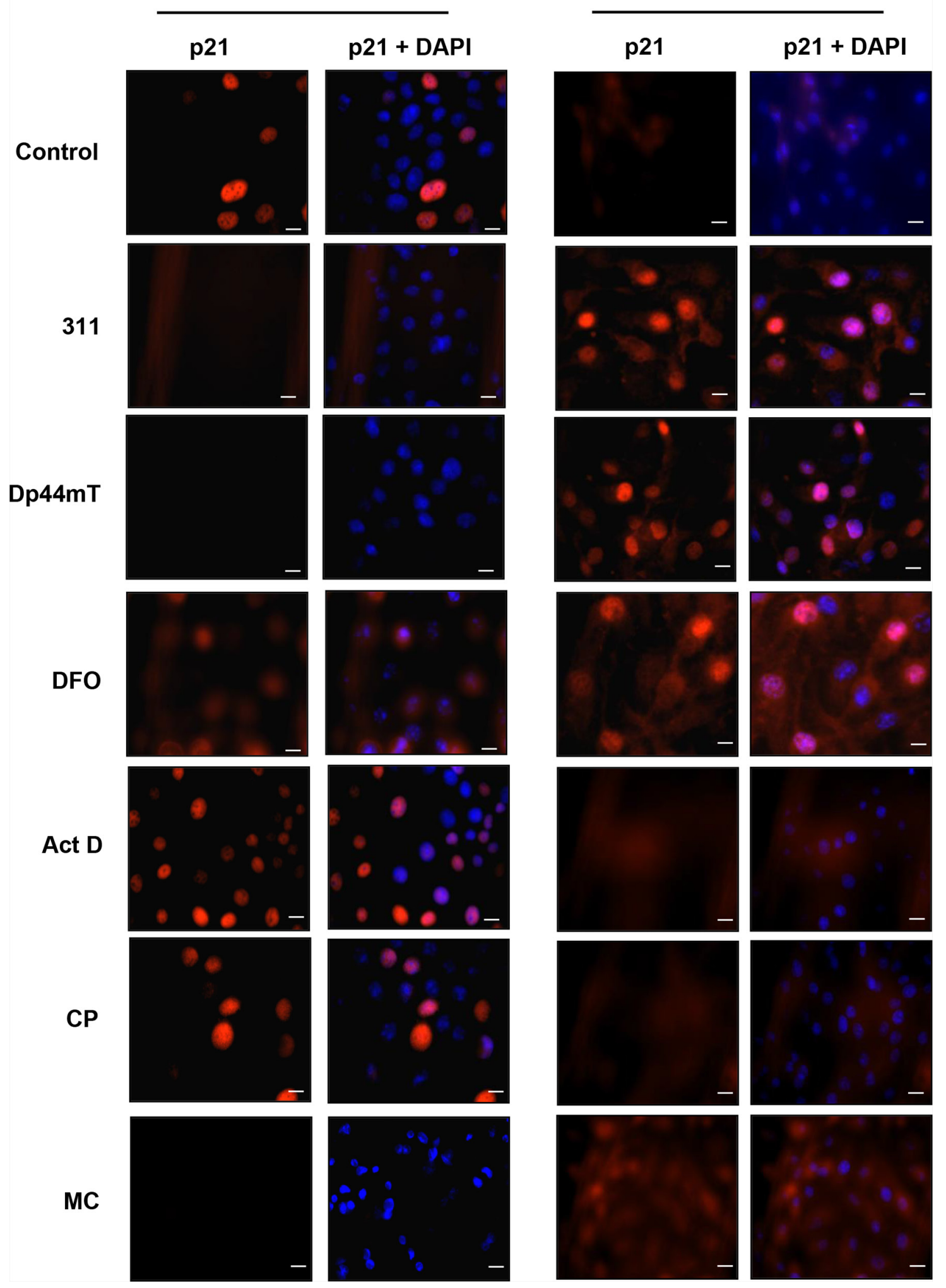

Figure 6: Immunofluorescence studies examining the cellular distribution of p21 observed in: A. MCF-7 cells, or B. SK-MEL-28 cells, in response to chelators or DNA-damaging agents. Cells were incubated for $24 \mathrm{~h} / 37^{\circ} \mathrm{C}$ with the chelators, $311(25 \mu \mathrm{M})$, Dp44mT $(2.5 \mu \mathrm{M})$, DFO $(250 \mu \mathrm{M})$, or the DNA-damaging agents, Act D $(5 \mathrm{nM})$, CP $(20 \mu \mathrm{M})$, or MC $(30 \mu \mathrm{M})$. Photographs were taken from cells incubated with primary p21 antibody and Alexa Fluor ${ }^{\circledR} 594$ fluorescent dye conjugated secondary antibody and 4', 6-diamidino-2-phenylindole (DAPI). An electronic merge of both photos was used to demonstrate the nuclear localization of p21. The photographs are typical of three experiments. The scale bar in each image represents $20 \mu \mathrm{m}$. 
Recently, NDRG1 was found to up-regulate p21 mRNA and protein in PC3 and DU145 prostate cancer cells and H1299 lung cancer cells, independently of p53 [41]. NDRG1 functions as a metastasis suppressor in various cancers (for review see [97]) and has been shown to be up-regulated in response to Fe chelator treatment in a variety of cell-types $[12,41]$. The increased expression of NDRG1 in response to Fe-deprivation in all the cell lines used in this investigation agreed with that previously observed in prostate and lung cancer cell lines [41]. However, NDRG1 did not directly correlate with p21 protein expression in MCF-7, LNCaP, or SK-N-MC cells, suggesting that alternative, NDRG1-independent pathways could be involved in the chelator-mediated effects on p21 in these cell-types.

As previously mentioned, MDM2 has been reported to regulate the expression of $\mathrm{p} 21$ independently of p53, by directly promoting its proteasomal degradation [56, 57]. The many MDM 2 isoforms arise through proteolytic cleavage, post-translational modification, or alternative splicing [78, 79]. Considering this, Cheng and Cohen [98] reported that the $\mathrm{p} 90^{\mathrm{MDM} 2}$ isoform is an un-conjugated fulllength MDM2 protein, whereas p $75^{\mathrm{MDM} 2}$ is an $N$-terminal truncated protein isoform. The over-expression of $\mathrm{p} 75^{\mathrm{MDM} 2}$, which cannot bind $\mathrm{p} 53$, has been found to interfere with the ability of $\mathrm{p} 90^{\mathrm{MDM} 2}$ to promote $\mathrm{p} 53$ degradation [62]. Several isoforms of MDM2 were identified in the cells used in this investigation (Fig. 4A-4D). Of particular interest, the $\mathrm{p} 75^{\mathrm{MDM} 2}$ isoform showed a close correlation to the expression of p21 in three of the five cell lines examined under all treatment conditions. In this case, the chelators appear to have activated the MDM2 promoter independently of $\mathrm{p} 53$, resulting in the generation of the $\mathrm{p} 75^{\mathrm{MDM} 2}$ isoform, which may in turn interfere with the ability of $\mathrm{p} 90^{\mathrm{MDM} 2}$ to promote $\mathrm{p} 21$ degradation [56]. Besides its effects on $\mathrm{p} 53$ and $\mathrm{p} 21$, full-length MDM2 has a number of other oncogenic functions in cancer cells, which include the alteration of cell proliferation, apoptosis, invasion and metastasis $[99,100]$. However, the exact mechanisms by which chelators modulate MDM2 function are unknown and further studies are required to elucidate how, and why, particular isoforms are affected in response to Fe chelation.

Another member of the p53 family, p63, has also been found to contain multiple isoforms with various activities [83, 84]. The TAp63 isoform, which contains the transactivation domain, has transcriptional activity and transactivates p53 target genes such as p21 and MDM2 $[83,101]$. The $\Delta \mathrm{Np} 63$ isoform lacks the transactivation domain and its over expression has previously been reported as a negative regulator of p21 [58, 60, 61]. However, this study indicated that the alterations in p21 observed in these cell-types were independent of $\Delta \mathrm{Np} 63$ expression, with no changes in $\Delta \mathrm{Np} 63$ detected in response to the chelators.

Finally, this investigation demonstrated that for SK-MEL-28 and CFPAC-1 cells there was increased nuclear localization of p21 compared to cytosolic levels in response to chelators. Given the inhibitory effects of p21 when localized to the nucleus [45], which include its cdk inhibitory function and promotion of cellular senescence, the nuclear accumulation of $\mathrm{p} 21$ observed could explain how chelators lead to $\mathrm{G}_{1} / \mathrm{S}$ arrest in these cell-types $[21,25]$. Considering that p21 can aid in cell cycle progression by stabilising the interactions between cyclins and cdks under certain conditions [45, $49,50]$, the decrease in the endogenously high levels of p21 in MCF-7 cells in response to chelators may partially explain their anti-proliferative activity in this cell line [23].

In conclusion, this study examined the mechanisms involved in the chelator-mediated regulation of p21 in five tumor cell lines. Overall, the results indicated that chelators regulate $\mathrm{p} 21$ expression independently of p53 status and in a cell line-dependent manner. Furthermore, we identified that the $75 \mathrm{kDa}$ isoform of MDM2 (p75 ${ }^{\mathrm{MDM} 2}$ ) closely resembled the expression of p21 in response to Fe chelators in three of the five cell lines examined, suggesting that MDM2 may be involved in the regulation of $\mathrm{p} 21$ protein in response to these agents.

\section{METHODS}

\section{Cell culture}

Cells were purchased from the American Type Culture Collection (ATCC; MD, USA). These include: the human breast cancer cell line, MCF-7; the androgensensitive human prostate adenocarcinoma cells, $\mathrm{LNCaP}$; the human melanoma cell line, SK-MEL-28; the human pancreatic ductal adenocarcinoma cell line, CFPAC-1; and the neuroepithelioma cell line derived from a supra orbital brain tumor, SK-N-MC. The MCF-7, SK-MEL-28 and SK-N-MC cell lines were maintained in Minimal Essential Medium (MEM; Invitrogen; CA, USA). The CFPAC-1 cell line was maintained in Dulbecco's Modified Eagle Medium (DMEM; Invitrogen), whereas the LNCaP cell line was maintained in Roswell Park Memorial Institute medium (RPMI; Invitrogen). All media was supplemented with $10 \%$ fetal calf serum (FCS; Sigma Aldrich; MO, USA), $100 \mu \mathrm{g} / \mathrm{mL}$ penicillin/streptomycin/ glutamine (Invitrogen), $0.1 \mathrm{mM}$ non-essential amino acids (Invitrogen), $1 \mathrm{mM}$ sodium pyruvate (Invitrogen) and 0.28 $\mathrm{ng} / \mathrm{mL}$ Fungizone ${ }^{\mathrm{TM}}$ (Invitrogen). Cells were grown at $37^{\circ} \mathrm{C}$ in $5 \% \mathrm{CO}_{2}$ in a cell culture incubator.

\section{Cell treatments}

Cells were treated with various chelators, including: DFO (Novartis; Basel, Switzerland) at $250 \mu \mathrm{M}, 311$ at $25 \mu \mathrm{M}, \mathrm{Dp} 44 \mathrm{mT}$ at $2.5 \mu \mathrm{M}$, and the DNA-damaging agents, Act D at $5 \mathrm{nM}$ (Sigma Aldrich; MO, USA); $\mathrm{CP}$ at $20 \mu \mathrm{M}$ (Sigma Aldrich); MC at $30 \mu \mathrm{M}$ (Sigma 
Aldrich) for a period of $24 \mathrm{~h} / 37^{\circ} \mathrm{C}$. The ligands, 311 and Dp44mT were synthesized and characterized by standard methods $[35,102]$. All agents were dissolved directly in culture media excluding 311 and Dp44mT, which were initially dissolved in dimethyl sulfoxide (DMSO; Sigma Aldrich) and then diluted in culture media (final DMSO concentration was $\leq 0.25 \%(\mathrm{v} / \mathrm{v}))$.

\section{RNA isolation and RT-PCR}

RNA was isolated using TRI Reagent Solution, following the manufacturer's protocol (Applied Biosystems; CA, USA). Reverse transcription-polymerase chain reaction (RT-PCR) was performed according to the methodology described in [70] using the primers provided in Supplementary Table 1.

\section{Western blot analysis}

Protein was extracted from either whole cell lysates, as described previously [9], or nuclear and cytoplasmic fractions using the NE-PER Nuclear and Cytoplasmic Extraction Reagent Kit (Pierce; IL, USA). Western blot analysis was performed via established methods [9]. Primary antibodies used were against p21 (1:1000; Cat.\#: 2947S; Cell Signaling Technology, MA, USA); NDRG1 (1:2000; Cat.\#: ab37897; Abcam, Cambridge, UK); HDAC1 (1:1000; Cat.\#: 2062S; Cell Signaling); MDM2-SMP14 (1:1000; Cat.\#: sc-965; Sigma Aldrich); and $\Delta$ Np63 (1:400; Cat.\#: sc-8609; Santa Cruz Biotechnology; CA, USA). The secondary antibodies used were all conjugated to horseradish peroxidase (HRP) and include: anti-rabbit IgG, anti-goat IgG and anti-mouse IgG (1:10,000; Cat.\#: A0545, A5420, A9917; Sigma Aldrich). $\beta$-actin (1:10,000; Cat.\#: A5316; Sigma Aldrich) was used as a protein-loading control.

In some experiments, due to electrophoresis hardware constraints, samples from one experiment were required to be run on 2 gels at the same time. These were then exposed equally under exactly the same conditions at the same time. When this was done, a vertical line is shown in the gel (i.e., see Fig. 5).

\section{Immunofluorescence}

Immunofluorescence was performed by established methods, as described previously [10]. Briefly, cells were seeded onto coverslips and fixed in ice-cold methanol for $15 \mathrm{~min}$ and then permeabilized with PBS containing $0.25 \%$ Triton X-100 for $10 \mathrm{~min}$ at room temperature. The cells were then incubated with the p21 primary antibody (1:400) above, overnight at $4^{\circ} \mathrm{C}$. This procedure was then followed by incubation with the secondary antibody, namely anti-rabbit Ab conjugated to Alexa Fluor ${ }^{\circledR} 594$ fluorescent dye (1:1000; Cat.\#: A11012; Cell Signaling) for $1 \mathrm{~h}$ at room temperature. The coverslips were mounted onto slides using an anti-fade mounting solution containing 4',6-diamidino-2-phenylindole (DAPI; Invitrogen). The slides were then analysed using a Zeiss Axio Observer.Z1 fluorescent microscope and images were taken and analysed using Axiovision software (Carl Zeiss AG, Oberkochen, Germany).

\section{Densitometry and statistical analysis}

Densitometry was performed using Quantity One software (Bio-Rad, Hercules, CA) and normalised using the relative $\beta$-actin loading control. Results are typical of three to six independent experiments and presented as mean \pm S.D. Experimental data were compared using the Student's $t$-test. Results were considered statistically significant when $p<0.05$.

\section{ACKNOWLEDGMENTS}

R.S.M. sincerely appreciates an Australian Rotary Health/Rotary Club of Liverpool West Funding Partner Scholarship. Z.K. thanks the NHMRC and CINSW for Early Career Fellowships. D.R.R. thanks the NHMRC for a Senior Principal Research Fellowship and Project Grant funding. We appreciated comments on the manuscript prior to submission from Dr. Hiu Lok, Dr. Goldie Lui, Miss Sharleen Menezes, Dr. Vera Richardson, Dr. Sumit Sahni and Dr. Nicole Seebacher (Molecular Pharmacology and Pathology Program, University of Sydney).

\section{FUNDING}

Australian Rotary Health/Rotary Club of Liverpool West Funding Partner Scholarship; NHMRC Early Career Fellowship; CINSW Early Career Fellowship; NHMRC Project Grants; NHMRC Senior Principal Research Fellowship.

\section{CONFLICTS OF INTEREST}

No conflict.

\section{REFERENCES}

1. Estrov Z, Tawa A, Wang XH, Dube ID, Sulh H, Cohen A, Gelfand $\mathrm{EW}$, Freedman $\mathrm{MH}$. In vitro and in vivo effects of deferoxamine in neonatal acute leukemia. Blood. 1987; 69:757-761.

2. Noulsri E, Richardson DR, Lerdwana S, Fucharoen S, Yamagishi T, Kalinowski DS, Pattanapanyasat K. Antitumor activity and mechanism of action of the iron chelator, Dp44mT, against leukemic cells. Am J Hematol. 2009; 84:170-176. 
3. Lederman HM, Cohen A, Lee JW, Freedman MH, Gelfand EW. Deferoxamine: a reversible S-phase inhibitor of human lymphocyte proliferation. Blood. 1984; 64:748-753.

4. Blatt J, Stitely S. Antineuroblastoma activity of desferoxamine in human cell lines. Cancer Res. 1987; 47:1749-1750.

5. Donfrancesco A, Deb G, Dominici C, Pileggi D, Castello MA, Helson L. Effects of a single course of deferoxamine in neuroblastoma patients. Cancer Res. 1990; 50:4929-4930.

6. Le NT, Richardson DR. The role of iron in cell cycle progression and the proliferation of neoplastic cells. Biochim Biophys Acta. 2002; 1603:31-46.

7. Chaston TB, Lovejoy DB, Watts RN, Richardson DR. Examination of the antiproliferative activity of iron chelators: multiple cellular targets and the different mechanism of action of triapine compared with desferrioxamine and the potent pyridoxal isonicotinoyl hydrazone analogue 311 . Clin Cancer Res. 2003; 9:402-414.

8. Kulp KS, Green SL, Vulliet PR. Iron deprivation inhibits cyclin-dependent kinase activity and decreases cyclin $\mathrm{D} / \mathrm{CDK} 4$ protein levels in asynchronous MDA-MB-453 human breast cancer cells. Exp Cell Res. 1996; 229:60-68.

9. Gao J, Richardson DR. The potential of iron chelators of the pyridoxal isonicotinoyl hydrazone class as effective antiproliferative agents, IV: The mechanisms involved in inhibiting cell-cycle progression. Blood. 2001; 98:842-850.

10. Liang SX, Richardson DR. The effect of potent iron chelators on the regulation of $\mathrm{p} 53$ : examination of the expression, localization and DNA-binding activity of p53 and the transactivation of WAF1. Carcinogenesis. 2003; 24:1601-1614.

11. Yu Y, Kovacevic Z, Richardson DR. Tuning cell cycle regulation with an iron key. Cell Cycle. 2007; 6:1982-1994.

12. Le NT, Richardson DR. Iron chelators with high antiproliferative activity up-regulate the expression of a growth inhibitory and metastasis suppressor gene: a link between iron metabolism and proliferation. Blood. 2004; 104:2967-2975.

13. Buss JL, Greene BT, Turner J, Torti FM, Torti SV. Iron chelators in cancer chemotherapy. Curr Top Med Chem. 2004; 4:1623-1635.

14. Dixon KM, Lui GY, Kovacevic Z, Zhang D, Yao M, Chen Z, Dong Q, Assinder SJ, Richardson DR. Dp44mT targets the AKT, TGF-beta and ERK pathways via the metastasis suppressor NDRG1 in normal prostate epithelial cells and prostate cancer cells. Br J Cancer. 2013; 108:409-419.

15. Kalinowski DS, Richardson DR. The evolution of iron chelators for the treatment of iron overload disease and cancer. Pharmacol Rev. 2005; 57:547-583.

16. Merlot AM, Kalinowski DS, Richardson DR. Novel chelators for cancer treatment: where are we now? Antioxid Redox Signal. 2013; 18:973-1006.
17. Blatt J. Deferoxamine in children with recurrent neuroblastoma. Anticancer Res. 1994; 14:2109-2112.

18. Sahni S, Krishan S, Richardson DR. NDRG1 as a molecular target to inhibit the epithelial-mesenchymal transition: the case for developing inhibitors of metastasis. Future Med Chem. 2014; 6:1241-1244.

19. Richardson D, Ponka P, Baker E. The effect of the iron(III) chelator, desferrioxamine, on iron and transferrin uptake by the human malignant melanoma cell. Cancer Res. 1994; 54:685-689.

20. Richardson DR, Tran EH, Ponka P. The potential of iron chelators of the pyridoxal isonicotinoyl hydrazone class as effective antiproliferative agents. Blood. 1995; $86: 4295-4306$.

21. Richardson DR, Milnes K. The potential of iron chelators of the pyridoxal isonicotinoyl hydrazone class as effective antiproliferative agents II: the mechanism of action of ligands derived from salicylaldehyde benzoyl hydrazone and 2-hydroxy-1-naphthylaldehyde benzoyl hydrazone. Blood. 1997; 89:3025-3038.

22. Darnell G, Richardson DR. The potential of iron chelators of the pyridoxal isonicotinoyl hydrazone class as effective antiproliferative agents III: the effect of the ligands on molecular targets involved in proliferation. Blood. 1999; 94:781-792.

23. Yuan J, Lovejoy DB, Richardson DR. Novel di-2-pyridylderived iron chelators with marked and selective antitumor activity: in vitro and in vivo assessment. Blood. 2004; 104:1450-1458.

24. Whitnall M, Howard J, Ponka P, Richardson DR. A class of iron chelators with a wide spectrum of potent antitumor activity that overcomes resistance to chemotherapeutics. Proc Natl Acad Sci U S A. 2006; 103:14901-14906.

25. Kovacevic Z, Chikhani S, Lovejoy DB, Richardson DR. Novel thiosemicarbazone iron chelators induce up-regulation and phosphorylation of the metastasis suppressor $\mathrm{N}$-myc down-stream regulated gene 1: a new strategy for the treatment of pancreatic cancer. Mol Pharmacol. 2011; 80:598-609.

26. Liu W, Xing F, Iiizumi-Gairani M, Okuda H, Watabe M, Pai SK, Pandey PR, Hirota S, Kobayashi A, Mo YY, Fukuda K, Li Y, Watabe K. N-myc downstream regulated gene 1 modulates Wnt-beta-catenin signalling and pleiotropically suppresses metastasis. EMBO Mol Med. 2012; 4:93-108.

27. Chen Z, Zhang D, Yue F, Zheng M, Kovacevic Z, Richardson DR. The iron chelators Dp44mT and DFO inhibit TGF-beta-induced epithelial-mesenchymal transition via up-regulation of N-Myc downstream-regulated gene 1. J Biol Chem. 2012; 287:17016-17028.

28. Kovacevic Z, Chikhani S, Lui GY, Sivagurunathan S, Richardson DR. The iron-regulated metastasis suppressor NDRG1 targets NEDD4L, PTEN, and SMAD4 and inhibits 
the PI3K and Ras signaling pathways. Antioxid Redox Signal. 2013; 18:874-887.

29. Sun J, Zhang D, Zheng Y, Zhao Q, Zheng M, Kovacevic Z, Richardson DR. Targeting the metastasis suppressor, NDRG1, using novel iron chelators: regulation of stress fiber-mediated tumor cell migration via modulation of the ROCK1/pMLC2 signaling pathway. Mol Pharmacol. 2013; 83:454-469.

30. Jin R, Liu W, Menezes S, Yue F, Zheng M, Kovacevic Z, Richardson DR. The metastasis suppressor NDRG1 modulates the phosphorylation and nuclear translocation of betacatenin through mechanisms involving FRAT1 and PAK4. J Cell Sci. 2014; 127:3116-3130.

31. Liu W, Yue F, Zheng M, Merlot A, Bae DH, Huang M, Lane D, Jansson P, Lui GY, Richardson V, Sahni S, Kalinowski D, Kovacevic Z, et al. The proto-oncogene c-Src and its downstream signaling pathways are inhibited by the metastasis suppressor, NDRG1. Oncotarget. 2015; 6:8851-8874.

32. Jansson PJ, Yamagishi T, Arvind A, Seebacher N, Gutierrez E, Stacy A, Maleki S, Sharp D, Sahni S, Richardson DR. Di-2-pyridylketone 4,4-Dimethyl-3-thiosemicarbazone (Dp44mT) Overcomes Multidrug-Resistance by a Novel Mechanism Involving the Hijacking of Lysosomal P-Glycoprotein (Pgp). J Biol Chem. 2015; 290:9588-9603.

33. Lovejoy DB, Jansson PJ, Brunk UT, Wong J, Ponka P, Richardson DR. Antitumor activity of metal-chelating compound $\mathrm{Dp} 44 \mathrm{mT}$ is mediated by formation of a redox-active copper complex that accumulates in lysosomes. Cancer Res. 2011; 71:5871-5880.

34. Kalinowski DS, Yu Y, Sharpe PC, Islam M, Liao YT, Lovejoy DB, Kumar N, Bernhardt PV, Richardson DR. Design, synthesis, and characterization of novel iron chelators: structure-activity relationships of the 2-benzoylpyridine thiosemicarbazone series and their 3-nitrobenzoyl analogues as potent antitumor agents. J Med Chem. 2007; 50:3716-3729.

35. Richardson DR, Sharpe PC, Lovejoy DB, Senaratne D, Kalinowski DS, Islam M, Bernhardt PV. Dipyridyl thiosemicarbazone chelators with potent and selective antitumor activity form iron complexes with redox activity. J Med Chem. 2006; 49:6510-6521.

36. Yu Y, Kalinowski DS, Kovacevic Z, Siafakas AR, Jansson PJ, Stefani C, Lovejoy DB, Sharpe PC, Bernhardt PV, Richardson DR. Thiosemicarbazones from the old to new: iron chelators that are more than just ribonucleotide reductase inhibitors. J Med Chem. 2009; 52:5271-5294.

37. Fukuchi K, Tomoyasu S, Watanabe H, Kaetsu S, Tsuruoka N, Gomi K. Iron deprivation results in an increase in p53 expression. Biol Chem Hoppe Seyler. 1995; 376:627-630.

38. Ashcroft M, Taya Y, Vousden KH. Stress signals utilize multiple pathways to stabilize p53. Mol Cell Biol. 2000; 20:3224-3233.
39. Ko LJ, Prives C. p53: puzzle and paradigm. Genes Dev. 1996; 10:1054-1072.

40. el-Deiry WS, Tokino T, Velculescu VE, Levy DB, Parsons R, Trent JM, Lin D, Mercer WE, Kinzler KW, Vogelstein B. WAF1, a potential mediator of p53 tumor suppression. Cell. 1993; 75:817-825.

41. Kovacevic Z, Sivagurunathan S, Mangs H, Chikhani S, Zhang D, Richardson DR. The metastasis suppressor, $\mathrm{N}$-myc downstream regulated gene 1 , upregulates p21 via p53-independent mechanisms. Carcinogenesis. 2011; 32:732-740.

42. Harper JW, Adami GR, Wei N, Keyomarsi K, Elledge SJ. The p21 Cdk-interacting protein Cip1 is a potent inhibitor of G1 cyclin-dependent kinases. Cell. 1993; 75:805-816.

43. Xiong Y, Hannon GJ, Zhang H, Casso D, Kobayashi R, Beach D. p21 is a universal inhibitor of cyclin kinases. Nature. 1993; 366:701-704.

44. Engelman RW, Jackson RJ, Coppola D, Wharton W, Cantor $\mathrm{AB}$, Pledger WJ. Loss of nuclear p21(Cip1/WAF1) during neoplastic progression to metastasis in gamma-irradiated p21 hemizygous mice. Exp Mol Pathol. 2007; 82:234-244.

45. Child ES, Mann DJ. The intricacies of $\mathrm{p} 21$ phosphorylation: protein/protein interactions, subcellular localization and stability. Cell Cycle. 2006; 5:1313-1319.

46. Ogryzko VV, Wong P, Howard BH. WAF1 retards S-phase progression primarily by inhibition of cyclin-dependent kinases. Mol Cell Biol. 1997; 17:4877-4882.

47. Roninson IB. Oncogenic functions of tumour suppressor p21(Waf1/Cip1/Sdi1): association with cell senescence and tumour-promoting activities of stromal fibroblasts. Cancer Lett. 2002; 179:1-14.

48. Dotto GP. p21(WAF1/Cip1): more than a break to the cell cycle?. Biochim Biophys Acta. 2000; 1471:M43-56.

49. Gartel AL, Radhakrishnan SK. Lost in transcription: p21 repression, mechanisms, and consequences. Cancer Res. 2005; 65:3980-3985.

50. LaBaer J, Garrett MD, Stevenson LF, Slingerland JM, Sandhu C, Chou HS, Fattaey A, Harlow E. New functional activities for the 21 family of CDK inhibitors. Genes Dev. 1997; 11:847-862.

51. Weiss RH. p21Waf1/Cip1 as a therapeutic target in breast and other cancers. Cancer Cell. 2003; 4:425-429.

52. Chang LC, Sheu HM, Huang YS, Tsai TR, Kuo KW. A novel function of emodin: enhancement of the nucleotide excision repair of UV- and cisplatin-induced DNA damage in human cells. Biochem Pharmacol. 1999; 58:49-57.

53. Froelich JJ, Schneller FR, Zahn RK. The influence of radiation and chemotherapy-related DNA strand breaks on carcinogenesis: an evaluation. Clin Chem Lab Med. 1999; 37:403-408.

54. Robles SJ, Adami GR. Agents that cause DNA double strand breaks lead to p16INK4a enrichment and the 
premature senescence of normal fibroblasts. Oncogene. 1998; 16:1113-1123.

55. Teng SP, Woodson SA, Crothers DM. DNA sequence specificity of mitomycin cross-linking. Biochemistry (Mosc). 1989; 28:3901-3907.

56. Zhang Z, Wang H, Li M, Agrawal S, Chen X, Zhang R. MDM2 is a negative regulator of $\mathrm{p} 21 \mathrm{WAF} 1 / \mathrm{CIP} 1$, independent of p53. J Biol Chem. 2004; 279:16000-16006.

57. Jin Y, Lee H, Zeng SX, Dai MS, Lu H. MDM2 promotes p21waf1/cip1 proteasomal turnover independently of ubiquitylation. EMBO J. 2003; 22:6365-6377.

58. Harmes DC, Bresnick E, Lubin EA, Watson JK, Heim KE, Curtin JC, Suskind AM, Lamb J, DiRenzo J. Positive and negative regulation of deltaN-p63 promoter activity by p53 and deltaN-p63-alpha contributes to differential regulation of p53 target genes. Oncogene. 2003; 22:7607-7616.

59. Chiang CT, Chu WK, Chow SE, Chen JK. Overexpression of delta Np63 in a human nasopharyngeal carcinoma cell line downregulates CKIs and enhances cell proliferation. J Cell Physiol. 2009; 219:117-122.

60. Yang A, Kaghad M, Wang Y, Gillett E, Fleming MD, Dotsch V, Andrews NC, Caput D, McKeon F. p63, a p53 homolog at 3q27-29, encodes multiple products with transactivating, death-inducing, and dominant-negative activities. Mol Cell. 1998; 2:305-316.

61. Nayak KB, Kuila N, Das Mohapatra A, Panda AK, Chakraborty S. EVI1 targets DeltaNp63 and upregulates the cyclin dependent kinase inhibitor p21 independent of p53 to delay cell cycle progression and cell proliferation in colon cancer cells. Int J Biochem Cell Biol. 2013; 45:1568-1576.

62. Perry ME, Mendrysa SM, Saucedo LJ, Tannous P, Holubar M. p76(MDM2) inhibits the ability of p90(MDM2) to destabilize p53. J Biol Chem. 2000; 275:5733-5738.

63. Ito A, Kawaguchi Y, Lai CH, Kovacs JJ, Higashimoto Y, Appella E, Yao TP. MDM2-HDAC1-mediated deacetylation of p53 is required for its degradation. EMBO J. 2002; 21:6236-6245.

64. Wu X, Bayle JH, Olson D, Levine AJ. The p53-mdm-2 autoregulatory feedback loop. Genes Dev. 1993; 7:1126-1132.

65. Jackson P, Grimm MO, Kingsley EA, Brosius U, Antalis T, Yardley G, Russell PJ. Relationship between expression of KAI1 metastasis suppressor gene, mRNA levels and p53 in human bladder and prostate cancer cell lines. Urol Oncol. 2002; 7:99-104.

66. O'Connor PM, Jackman J, Bae I, Myers TG, Fan S, Mutoh M, Scudiero DA, Monks A, Sausville EA, Weinstein JN, Friend S, Fornace AJ Jr., Kohn KW. Characterization of the p53 tumor suppressor pathway in cell lines of the National Cancer Institute anticancer drug screen and correlations with the growth-inhibitory potency of 123 anticancer agents. Cancer Res. 1997; 57:4285-4300.

67. Wosikowski K, Regis JT, Robey RW, Alvarez M, Buters JT, Gudas JM, Bates SE. Normal p53 status and function despite the development of drug resistance in human breast cancer cells. Cell Growth Differ. 1995; 6:1395-1403.

68. Redston MS, Caldas C, Seymour AB, Hruban RH, da Costa L, Yeo CJ, Kern SE. p53 mutations in pancreatic carcinoma and evidence of common involvement of homocopolymer tracts in DNA microdeletions. Cancer Res. 1994; 54:3025-3033.

69. Moll UM, Ostermeyer AG, Haladay R, Winkfield B, Frazier M, Zambetti G. Cytoplasmic sequestration of wildtype p53 protein impairs the G1 checkpoint after DNA damage. Mol Cell Biol. 1996; 16:1126-1137.

70. Fu D, Richardson DR. Iron chelation and regulation of the cell cycle: 2 mechanisms of posttranscriptional regulation of the universal cyclin-dependent kinase inhibitor p21CIP1/ WAF1 by iron depletion. Blood. 2007; 110:752-761.

71. Le NT, Richardson DR. Potent iron chelators increase the mRNA levels of the universal cyclin-dependent kinase inhibitor p21(CIP1/WAF1), but paradoxically inhibit its translation: a potential mechanism of cell cycle dysregulation. Carcinogenesis. 2003; 24:1045-1058.

72. Lui GY, Obeidy P, Ford SJ, Tselepis C, Sharp DM, Jansson PJ, Kalinowski DS, Kovacevic Z, Lovejoy DB, Richardson DR. The iron chelator, deferasirox, as a novel strategy for cancer treatment: oral activity against human lung tumor xenografts and molecular mechanism of action. Mol Pharmacol. 2013; 83:179-190.

73. Chang-Liu CM, Woloschak GE. Effect of passage number on cellular response to DNA-damaging agents: cell survival and gene expression. Cancer Lett. 1997; 113:77-86.

74. Murray JT, Campbell DG, Morrice N, Auld GC, Shpiro N, Marquez R, Peggie M, Bain J, Bloomberg GB, Grahammer F, Lang F, Wulff P, Kuhl D, et al. Exploitation of KESTREL to identify NDRG family members as physiological substrates for SGK1 and GSK3. Biochem J. 2004; 384:477-488.

75. Ghalayini MK, Dong Q, Richardson DR, Assinder SJ. Proteolytic cleavage and truncation of NDRG1 in human prostate cancer cells, but not normal prostate epithelial cells. Biosci Rep. 2013; 33:451-461.

76. Tanaka H, Arakawa H, Yamaguchi T, Shiraishi K, Fukuda S, Matsui K, Takei Y, Nakamura Y. A ribonucleotide reductase gene involved in a p53-dependent cell-cycle checkpoint for DNA damage. Nature. 2000; 404:42-49.

77. Nelson WG, Kastan MB. DNA strand breaks: the DNA template alterations that trigger p53-dependent DNA damage response pathways. Mol Cell Biol. 1994; 14:1815-1823.

78. Olson DC, Marechal V, Momand J, Chen J, Romocki C, Levine AJ. Identification and characterization of multiple $\mathrm{mdm}-2$ proteins and mdm-2-p53 protein complexes. Oncogene. 1993; 8:2353-2360.

79. Evans SC, Viswanathan M, Grier JD, Narayana M, El-Naggar AK, Lozano G. An alternatively spliced HDM2 
product increases p53 activity by inhibiting HDM2. Oncogene. 2001; 20:4041-4049.

80. Buschmann T, Fuchs SY, Lee CG, Pan ZQ, Ronai Z. SUMO-1 modification of Mdm2 prevents its selfubiquitination and increases Mdm2 ability to ubiquitinate p53. Cell. 2000; 101:753-762.

81. Saucedo LJ, Myers CD, Perry ME. Multiple murine double minute gene 2 (MDM2) proteins are induced by ultraviolet light. J Biol Chem. 1999; 274:8161-8168.

82. Schmale H, Bamberger C. A novel protein with strong homology to the tumor suppressor p53. Oncogene. 1997; 15:1363-1367.

83. Chen $X$. The p53 family: same response, different signals? Mol Med Today. 1999; 5:387-392.

84. Lin YL, Sengupta S, Gurdziel K, Bell GW, Jacks T, Flores ER. p63 and p73 transcriptionally regulate genes involved in DNA repair. PLoS Genet. 2009; 5:e1000680.

85. Westfall MD, Mays DJ, Sniezek JC, Pietenpol JA. The Delta Np63 alpha phosphoprotein binds the p21 and 14-3-3 sigma promoters in vivo and has transcriptional repressor activity that is reduced by Hay-Wells syndrome-derived mutations. Mol Cell Biol. 2003; 23:2264-2276.

86. Schavolt KL, Pietenpol JA. p53 and Delta Np63 alpha differentially bind and regulate target genes involved in cell cycle arrest, DNA repair and apoptosis. Oncogene. 2007; 26:6125-6132.

87. Espana EM, Di Pascuale MA, He H, Kawakita T, Raju VK, Liu CY, Tseng SC. Characterization of corneal pannus removed from patients with total limbal stem cell deficiency. Invest Ophthalmol Vis Sci. 2004; 45:2961-2966.

88. Fotheringham JA, Mazzucca S, Raab-Traub N. Epstein barrvirus latent membrane protein-2A-induced DeltaNp63alpha expression is associated with impaired epithelial-cell differentiation. Oncogene. 2010; 29:4287-4296.

89. Krolewski B, Little JB. Overexpression of $\mathrm{p} 21$ protein in radiation-transformed mouse $10 \mathrm{~T}(1 / 2)$ cell clones. Mol Carcinog. 2000; 27:141-148.

90. Wong SC, Chan JK, Lee KC, Hsiao WL. Differential expression of p16/p21/p27 and cyclin D1/D3, and their relationships to cell proliferation, apoptosis, and tumour progression in invasive ductal carcinoma of the breast. J Pathol. 2001; 194:35-42.

91. McKenzie PP, Danks MK, Kriwacki RW, Harris LC. P21Waf1/Cip1 dysfunction in neuroblastoma: a novel mechanism of attenuating G0-G1 cell cycle arrest. Cancer Res. 2003; 63:3840-3844.

92. Winters ZE, Leek RD, Bradburn MJ, Norbury CJ, Harris AL. Cytoplasmic p21WAF1/CIP1 expression is correlated with HER-2/ neu in breast cancer and is an independent predictor of prognosis. Breast Cancer Res. 2003; 5:R242-249.

93. Shiraki K, Wagayama H. Cytoplasmic p21(WAF1/CIP1) expression in human hepatocellular carcinomas. Liver Int. 2006; 26:1018-1019.

94. Xia W, Chen JS, Zhou X, Sun PR, Lee DF, Liao Y, Zhou BP, Hung MC. Phosphorylation/cytoplasmic localization of p21Cip1/WAF1 is associated with HER2/neu overexpression and provides a novel combination predictor for poor prognosis in breast cancer patients. Clin Cancer Res. 2004; 10:3815-3824.

95. Abbas T, Dutta A. p21 in cancer: intricate networks and multiple activities. Nat Rev Cancer. 2009; 9:400-414.

96. Snodgrass RG, Collier AC, Coon AE, Pritsos CA. Mitomycin C inhibits ribosomal RNA: a novel cytotoxic mechanism for bioreductive drugs. J Biol Chem. 2010; 285:19068-19075.

97. Fang BA, Kovacevic Z, Park KC, Kalinowski DS, Jansson PJ, Lane DJ, Sahni S, Richardson DR. Molecular functions of the iron-regulated metastasis suppressor, NDRG1, and its potential as a molecular target for cancer therapy. Biochim Biophys Acta. 2014; 1845:1-19.

98. Cheng TH, Cohen SN. Human MDM2 isoforms translated differentially on constitutive versus p53-regulated transcripts have distinct functions in the p53/MDM2 and TSG101/MDM2 feedback control loops. Mol Cell Biol. 2007; 27:111-119.

99. Vargas DA, Takahashi S, Ronai Z. Mdm2: A regulator of cell growth and death. Adv Cancer Res. 2003; 89:1-34.

100. Chen X, Qiu J, Yang D, Lu J, Yan C, Zha X, Yin Y. MDM2 promotes invasion and metastasis in invasive ductal breast carcinoma by inducing matrix metalloproteinase-9. PLoS ONE. 2013; 8:e78794.

101. Lohrum MA, Vousden KH. Regulation and function of the p53-related proteins: same family, different rules. Trends Cell Biol. 2000; 10:197-202.

102. Richardson DR, Bernhardt PV. Crystal and molecular structure of 2-hydroxy-1-naphthaldehyde isonicotinoyl hydrazone (NIH) and its iron(III) complex: an iron chelator with anti-tumour activity. J Biol Inorg Chem. 1999; 4:266-273. 